\title{
Electricity Generation Options for a Future Low Carbon Energy Mix for Malaysia
}

\author{
Cheng Seong Khor ${ }^{1,2}$ and G. Lalchand ${ }^{2}$ \\ ${ }^{I}$ Chemical Engineering Department, Universiti Teknologi PETRONAS, \\ 32610 Seri Iskandar, Perak Darul Ridzuan, Malaysia \\ ${ }^{2}$ Academy of Sciences Malaysia, 20th Floor, West Wing, MATRADE Tower, \\ Jalan Sultan Haji Ahmad Shah off Jalan Tunku Abdul Halim, 50480 Kuala Lumpur
}

\begin{abstract}
Malaysia's electricity generation mix is mainly based on fossil fuels, particularly natural gas and coal with a smaller share of large hydroelectric and non-hydroelectric renewable energy resources. The present work aims to analyse and assess the ongoing search for alternatives to fossil fuel for electricity generation that the country has been pursuing both environmental preservation and national energy security considerations, thereby suggesting the way forward including potential options to be deliberated. This paper surveys alternative, both practical and theoretical that can be considered technically and economically attractive for Malaysia over the period to 2050. The overall national energy supply and demand situation are first analysed to develop projections that account for the role of renewable energy, particularly that of solar photovoltaic (PV). Next, the paper discusses the progress achieved, and the current status of the national solar PV industry presents the advantages or benefits offered and outlines the remaining challenges. In the same manner, electricity generation from the biogas produced from methane recovery in treating palm oil mill effluent (POME) is assessed. In the final analysis, the paper considers other potential low carbon power generation options to make up the Malaysian energy mix, which include small hydroelectricity, municipal solid waste decomposition in suitably-engineered landfills, nuclear energy using thorium-based technology, and renewable marine energy particularly ocean thermal energy conversion (OTEC), in tandem with savings expected from energy efficiency and conservation $(\mathrm{EE} \& \mathrm{C})$ initiatives.
\end{abstract}

Keywords: energy supply; energy demand; energy projections; energy mix; sustainable energy; low carbon

\section{INTRODUCTION}

Malaysia's primary energy supply consists of oil, gas, coal, hydroelectric, and renewable resources. The nation's electricity generation mix is also largely based on fossil fuels, particularly natural gas and coal with a small share of renewable energy (RE) resources, including hydroelectricity. As of 2015, a major share of the current generation mix (see Figure 1) is heavily dependent on fossil fuels (88.4\%) with the remaining contribution from hydroelectric (10.7\%) and non-hydroelectric renewables (o.8\%) (Energy Commission Malaysia 2016c). The search for alternatives to fossil fuels is vigorously pursued for environmental and energy security considerations.

Promoting sustainable future energy options augurs well for Malaysia to reduce the environmental impacts of air pollution, greenhouse gas (GHG) emissions, and the resulting climate change effects as well as to contribute towards waste management and cost control. Energy generated from indigenous renewable resources enhances primary energy security and also eliminates pollution from agricultural residues since a significant proportion of

*Corresponding author's e-mail: khorchengseong@gmail.com 
renewables use such materials. A key issue in energy production and management is how to quickly replace fuels such as coal and petroleum products, which produce carbon dioxide besides other toxic emissions, with other energy sources that can be generated without producing such emissions.

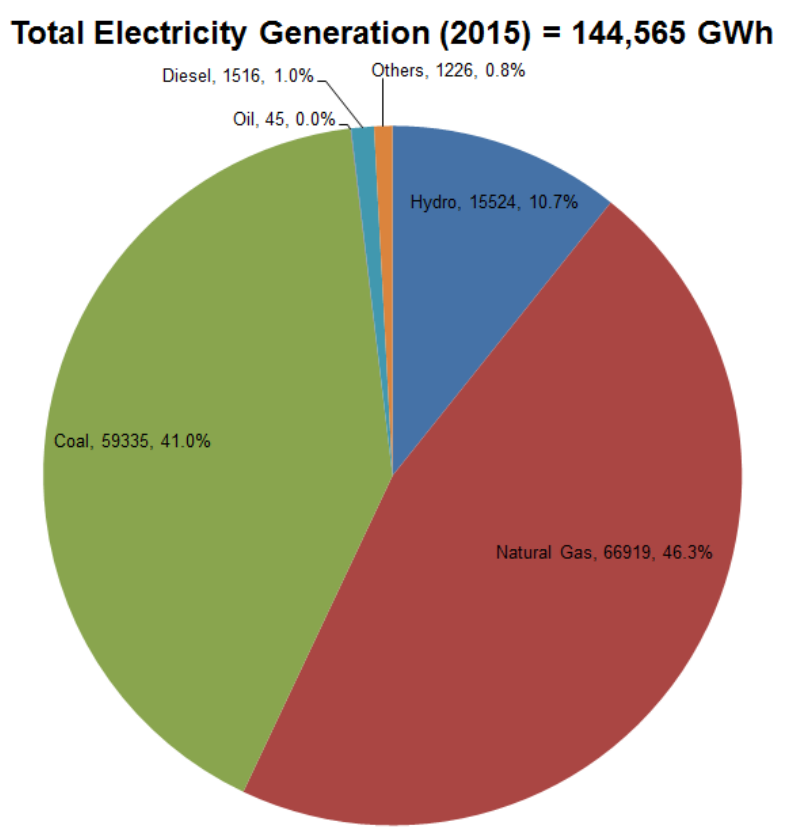

Figure 1. Malaysia: Electricity generation mix (GWh) in Malaysia for 2015 (Energy Commission Malaysia 2016c).

(Note: "Hydro" includes mini hydro; "Oil" includes distillate products; "Others" includes non-hydroelectric renewables such as biomass, solar, biogas, biomass and diesel (biodiesel), natural gas and diesel.)

A number of reviews are available covering various aspects, issues, and perspectives related to the Malaysian energy landscape particularly on RE (Ahmad et al., 2011; Hashim et al., 2011; Ong et al., 2011; Shafie et al., 2011; Mekhilef et al., 2014; Basri et al., 2015). A recent one is by Oh et al. (2018) with a similar focus on alternative, mainly renewable forms of energy for the Malaysian energy policy, which serves as an update to an earlier article by the same main author and one of the co-authors (Oh et al., 2010). Ahmad et al. (2014) present a numerical modelling approach for multiple-criteria decision making (called analytic hierarchy process) to select RE sources and technologies for developing a sustainable electricity generation system for Malaysia. This paper's authors have also published a critical review on sustainable options for electricity generation in Malaysia (Khor et al., 2014), intended as policy advisory representing the views of the Academy of Sciences Malaysia, which publishes this journal.

This paper analyses the opportunities for these energy options for Malaysia by reviewing the progress and status of renewable energy in Malaysia. By setting the premise of the present situation, the work aims to examine the prospect of renewable energy development and uptake in Malaysia, supported by quantitative analyses, and to highlight the remaining challenges ahead in the endeavour.

\section{CURRENT STATUS OF RENEWABLE ENERGY IN MALAYSIA}

Malaysia has a variety of RE resources that can be utilised for carbon free or low carbon electricity generation to displace reliance on fossil fuels. The available economically viable options have been detailed in the SEDA mechanism for the promotion of such renewable energy-powered electricity generation (Abdul Malek 2010). These have been restricted to small hydroelectricity, photovoltaic (PV), biomass and biogas (especially from palm oil plantation waste), solid waste particularly from municipals (i.e., MSW), and geothermal energy focusing on the geothermal power plant development project at Tawau in Sabah. In particular, Malaysia possesses substantial hydroelectric resource, especially in the East Malaysia state of Sarawak, which is by far the largest renewable energy resource deployed in the country. Large hydroelectric dams are also in operation in West Malaysia such as in Temengor, Perak and Kenyir, Terengganu.

The strategy of diversifying the nation's energy mix by including RE is aimed at increasing supply reliability and security by relying less on imported fossil fuels while continuing to monitor the overall reliability of the electricity generation and supply system. As regards promoting sustainability through renewable energy, Malaysia's electricity generation mix is planned to be less dependent on fossil fuels, which currently comprises about $46.3 \%$ from natural gas and $41.0 \%$ from coal in terms of energy (Energy Commission Malaysia 2016c).

On the whole, the major contributors to the planned RE generation capacity are PV, biomass and biogas, small hydro, 
waste to energy, and geothermal, as shown in Figure 2. Other potential RE options that are exploited in many countries such as marine RE (wave, tidal, and ocean thermal energy conversion (OTEC)), as well as wind (both onshore and offshore), have been excluded as their resource potential in Malaysia and the equatorial zone, in general, are found to be inadequate for commercial exploitation (SIRIM 2013).

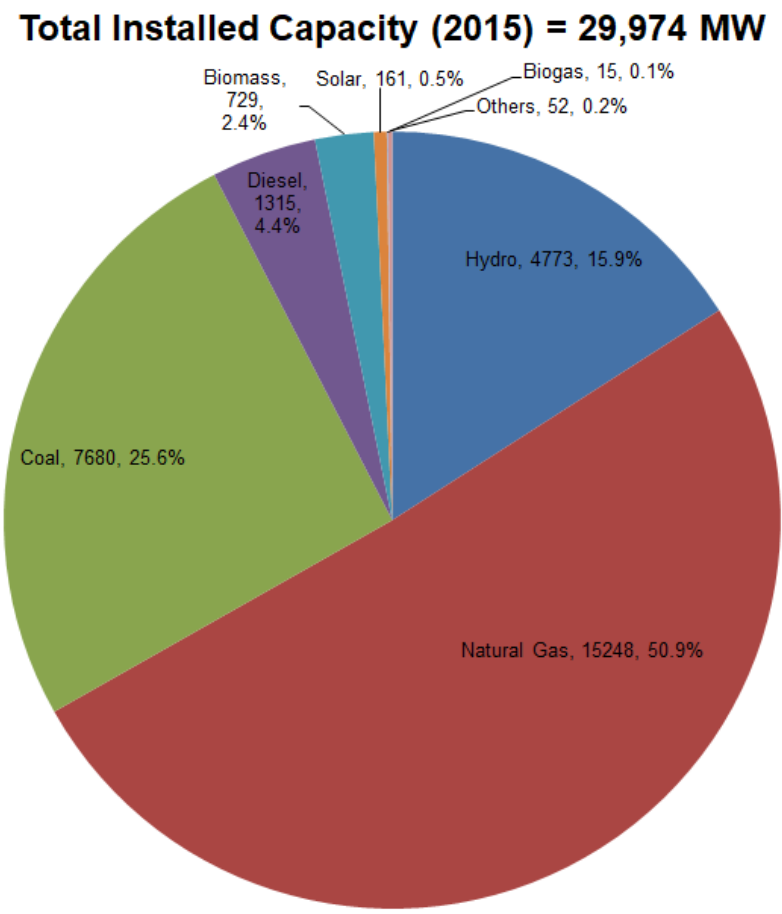

Figure 2. Installed power generation capacity (MW) (both on-grid and off-grid) in Malaysia for 2015 (Energy Commission Malaysia 2016b)

Contribution of renewables to the country's electricity generation mix has grown with the implementation of a feed-in tariff (FiT) scheme under the Renewable Energy Act 2011 (RE Act). The Act was supplemented by the formation of Sustainable Energy Development Authority (SEDA) as the legally designated agency for its implementation, supported by a funding mechanism to pay the increased or "top-up" tariff under FiT by way of a 1.6\% levy on the electricity bills for affected consumers.

RE Act particularly through FiT aimed to achieve a RE capacity share of $11 \%(2080 \mathrm{MW})$ in 2020 and $17 \%$ (400oMW) by 2030 for Peninsular Malaysia (i.e., excluding Sabah and Sarawak). FiT has promoted electricity generation from renewables, particularly from solar PV systems as the scheme is very lucrative, and it is easy to install PV systems quickly. The FiT regime for PV was terminated in 2017, but FiT for the other RE technologies remains.

Following the termination of the FiT scheme for PV, further promotion of PV systems was modified with greater emphasis on large scale solar (LSS) systems, which is also called utility-scale solar (USS) systems besides through the Net Energy Metering (NEM) scheme (see Section IV(A) for more details) and for self-consumption (SelCo), which aimed to maintain the high pace growth of solar PV capacity. These systems do not qualify for any FiT incentive but are based on NEM for SelCo and consumers' own, typically rooftop, installations.

The LSS/USS installations are however subject to tender auctions by the Malaysian Energy Commission (or Suruhanjaya Tenaga) at RE tariff rates based on the tendered quotes. They are paid directly by the authorised electricity suppliers (i.e., Tenaga Nasional Berhad (TNB) in Peninsular Malaysia or Sabah Electricity Sendirian Berhad (SESB) in the East Malaysia state of Sabah, referred to as the single buyer off-taker) under individual power purchase agreements.

The NEM and SelCo schemes did not take-off as well as expected because of perceived unfavourable tariffs offered; the "net energy" was not on actual net energy metering basis. The apparent drawback has been rectified recently by a decision by the Malaysian minister in charge of the energy portfolio (under the Ministry of Energy, Science, Technology, Environment and Climate Change or MESTECC) to make the NEM a true net energy metering and billing system (Yeo 2018). Such change and reclassification of NEM beginning January 2019 are anticipated to make the financial viability more attractive to prospective consumers to take advantage of the revised billing mechanism. Hence, going forward, the take-up capacity of NEM and SelCo is likely to accelerate.

Also, the MESTECC Minister has announced a revised national target for RE generating capacity share of $20 \%$ by 2025, which excludes large hydroelectric power plants. In this respect, the large hydroelectric plants are defined as those with generating capacity of over 100MW (see Table 1 for a list of hydroelectric plants in Malaysia grouped 
according to this classification).

In the Appendix of the paper, Section 9.1 provides a concise summary of policies related to energy, particularly renewable energy in Malaysia (see Table 14 and Figure 11). While various policies, programs, and initiatives have been undertaken to promote renewable energy in the country, the level of penetration attained still leaves room for improvement. Adopting a wider range of technologies is desirable as it has been acknowledged that there is not a silver bullet solution to address the energy trilemma of meeting energy needs for the nation's growth while ensuring environmental sustainability and promoting the welfare of the people.

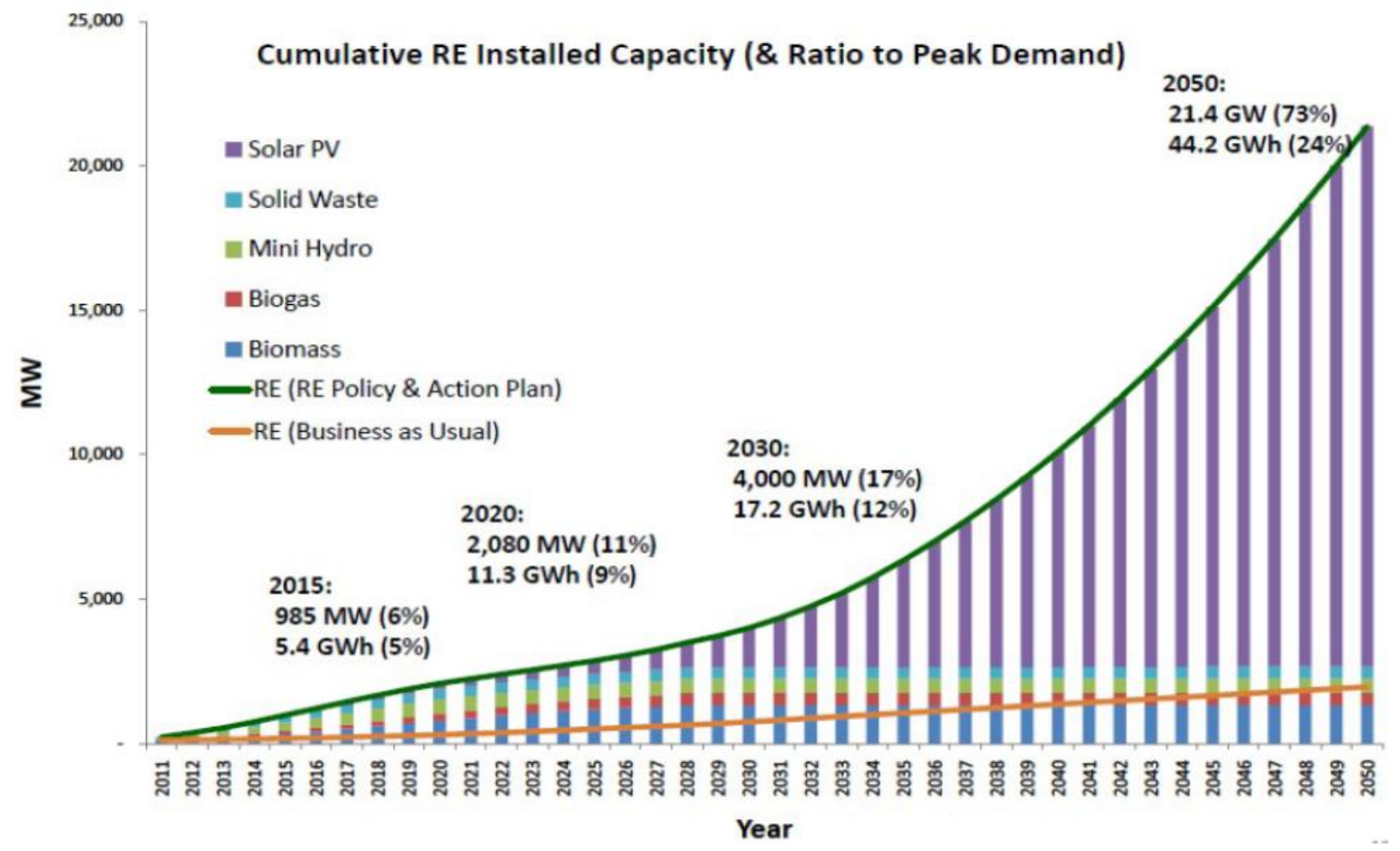

Figure 3. Malaysia: Current and projected cumulative renewable energy installed capacity (KeTTHA 2008b)

Table 1. Malaysia: Hydropower plants categorised according to generation capacity size

(Energy Commission Malaysia 2015b)

\begin{tabular}{|l|l|c|}
\hline \multicolumn{1}{|c|}{ State/River } & \multicolumn{1}{|c|}{ Location } & Capacity (MW) \\
\hline Capacity greater than 100MW & 348 \\
\hline Perak & Temengor & 120 \\
\cline { 2 - 3 } & Kenerong & 250 \\
\hline Pahang & Cameron Highlands (Jor and Woh) & 372 \\
\cline { 2 - 3 } & Ulu Jelai & 400 \\
\hline Terengganu & Sultan Mahmud Kenyir & 250 \\
\cline { 2 - 3 } & Hulu Terengganu & 600 \\
\hline Kelantan & Pergau & 108 \\
\hline Sarawak & Batang Ai & 2400 \\
\cline { 2 - 3 } & Bakun & 4848 \\
\cline { 2 - 3 } & Subtotal & \multicolumn{2}{|c|}{} \\
\hline
\end{tabular}




\begin{tabular}{|c|c|c|}
\hline \multicolumn{3}{|c|}{ Capacity less than 10oMW } \\
\hline \multirow[t]{4}{*}{ Perak/Sungai Perak } & Chenderoh & 40.5 \\
\hline & Bersia & 72 \\
\hline & Upper Piah (Sg. Piah Hulu) & 14.6 \\
\hline & Lower Piah (Sg. Piah Hilir) & 54 \\
\hline Pahang & Cameron Highlands & 11.9 \\
\hline \multirow[t]{2}{*}{ Kelantan } & Kenerong Upper & 12 \\
\hline & Kenerong Lower & 8 \\
\hline \multirow[t]{2}{*}{ Sabah } & Tenom Pangi & 69 \\
\hline & Subtotal & 282.0 \\
\hline \multicolumn{3}{|l|}{ Mini-hydro } \\
\hline \multirow[t]{7}{*}{ Perak } & Sungai Renyok & 1.6 \\
\hline & Sungai Perdak & 0.342 \\
\hline & Sungai Bil & 0.225 \\
\hline & Sungai Kinjang & 0.325 \\
\hline & Sungai Asap & 0.11 \\
\hline & Sungai Chempias & 0.12 \\
\hline & Sungai Tebing Tinggi & 0.152 \\
\hline \multirow[t]{3}{*}{ Kedah } & Sungai Tawar Besar & 0.552 \\
\hline & Sungai Mahang & 0.454 \\
\hline & Sungai Mempelam & \\
\hline \multirow[t]{4}{*}{ Terengganu } & Sungai Cheralak & 0.48 \\
\hline & Sungai Berang & 0.364 \\
\hline & Subtotal & 4.724 \\
\hline & Grant Total & 5134.724 \\
\hline
\end{tabular}

\section{MALAYSIA'S ENERGY SUPPLY AND DEMAND}

\section{A. Current Scenario}

Based on the Malaysian Energy Commission (or Suruhanjaya Tenaga) data as of 2015 (see Figure 2), the current renewables installed generation capacity including large scale hydroelectricity is $5730 \mathrm{MW}$ or $19.1 \%$ of the fuel mix (Energy Commission Malaysia 2016b). The installed capacity excluding large scale hydroelectricity is $957 \mathrm{MW}$ or $3.2 \%$ of the total. Note that the Energy Commission data may have reported a higher installed biomass capacity (801MW) than that of the SEDA data (142MW) due to the inclusion of self-generated electricity (i.e., non-grid connected) from palm oil mills.
In terms of 2015 energy generation, renewables including hydroelectricity contributed $11.6 \%(16,750 \mathrm{GWh})$ to the fuel mix; the figure is $0.9 \%(1226 \mathrm{GWh})$ without hydroelectricity. While the non-large-hydroelectric renewables share is forecast to increase to $20 \%$ by 2025 (Yeo 2018), its use is still to complement that of fossil fuels partly due to the intermittency effect of solar PV output and ease of access. Overall, the installed capacity and energy generation shares are mainly contributed by fossil fuels and large hydroelectricity.

Data for 2011 to 2015 shows an average consumption load factor of about $70 \%$, which is a ratio of electricity consumed to its maximum demand. Over the same period, an average capacity factor (ratio of electricity generated to its installed generation capacity) of greater than $50 \%$ is indicated for Malaysia. A study commissioned by the Academy of Sciences 
Malaysia reports both factors within the stated range (Akademi Sains Malaysia 2015).

\section{B. Energy Supply and Demand Projections}

Official statistics on the power generation capacity (in MW) mix for Peninsular Malaysia with projections to the year 2026 is shown in Figure 4. The projections show a large capacity increase from 2019 to 2020, which then stays fairly constant till 2024, but is then expected to decrease. No specific strategies that can contribute to such capacity (or demand) decline are indicated although the national energy efficiency or demand-side management (DSM) initiatives appear to be the main rationale for the projected demand trend. Based on the authors' awareness of similar initiatives for Denmark and California in the United States, such an eventuality is unlikely especially because Malaysia has yet to implement its DSM program (see Figure 5 and Figure 6which show rising energy trend for both locations). National DSM initiatives, when implemented, can help to moderate the demand growth rate over time.

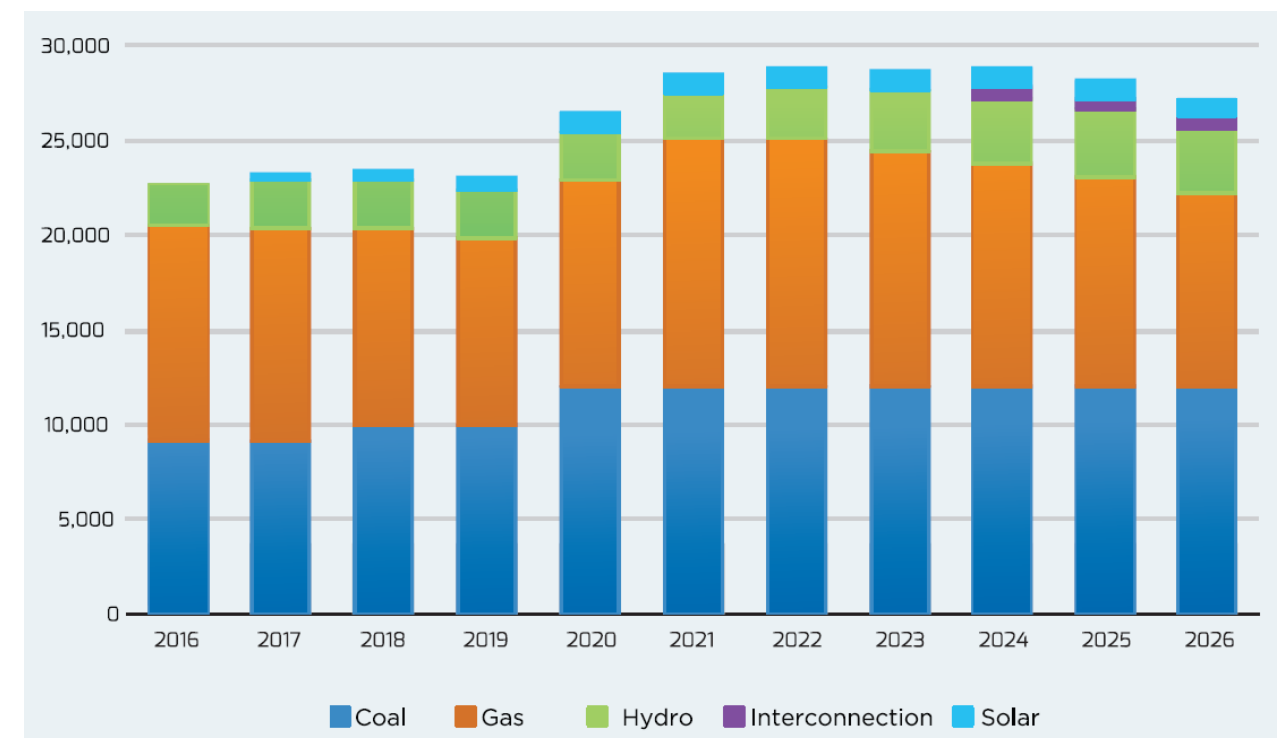

Figure 4. Peninsular Malaysia: Power generation capacity (in MW) mix with projections to 2026 (Energy Commission/Suruhanjaya Tenaga Malaysia 2017)

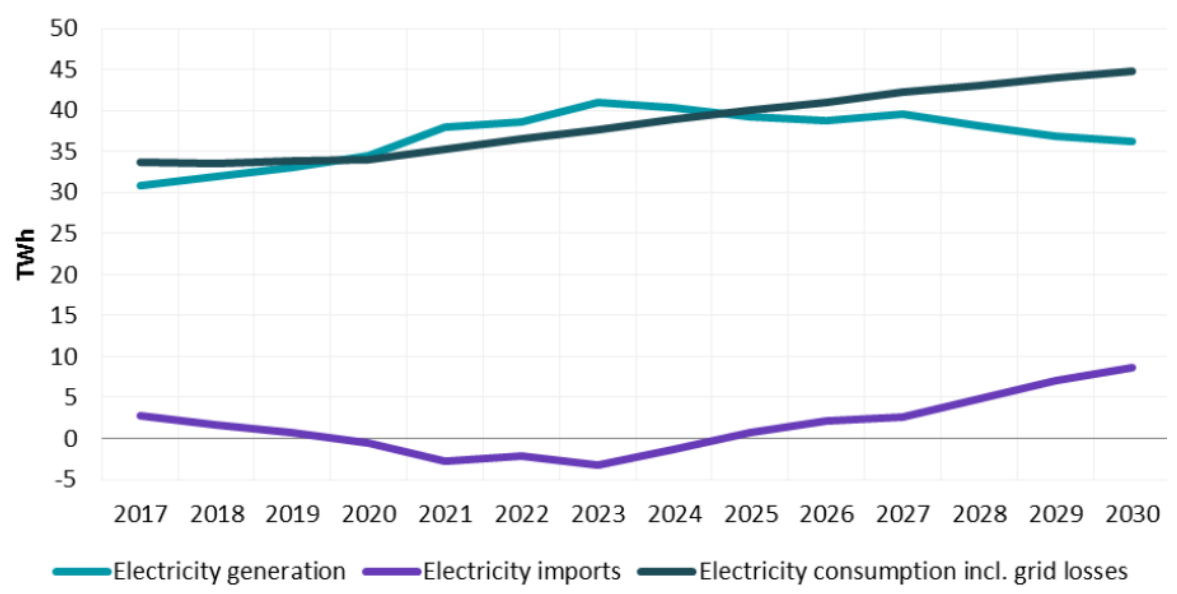

Figure 5. Denmark: Electricity consumption (projected in TWh), generation, and imports for 2017-2030 (Danish Energy Agency 2018) 


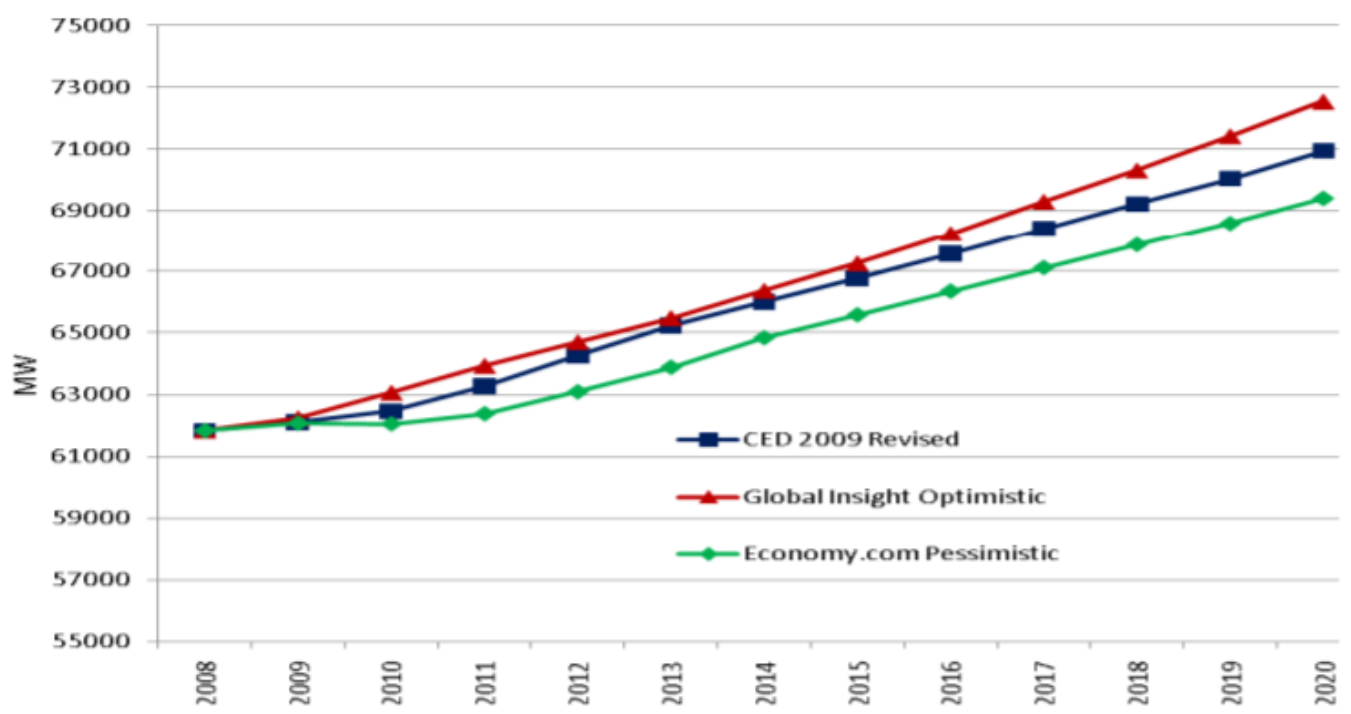

Figure 6. California (USA): Peak energy demand (projected in MW) for 2008-2020 (Kavalec and Gorin 2009)

To compare, such a decline in energy use is only seen after about three decades in a country such as Sweden. In the latter case, the reason can be attributed to its manufacturing industries moving abroad to take advantage of cheaper labor cost, which is partly reflected in its reduced final energy use in the residential and services sector observed over more than four decades (1971 to 2013) as shown in Figure 7 (Swedish Energy Agency 2015).
As Malaysia's energy demand is expected to continue to rise (Energy Commission Malaysia 2017), it is imperative for the energy supply sector to ensure adequate generation, transmission, and distribution facilities are in place to meet the nation's needs. The current and projected RE capacities under different categories of technologies and programs are tabulated in Table 2.

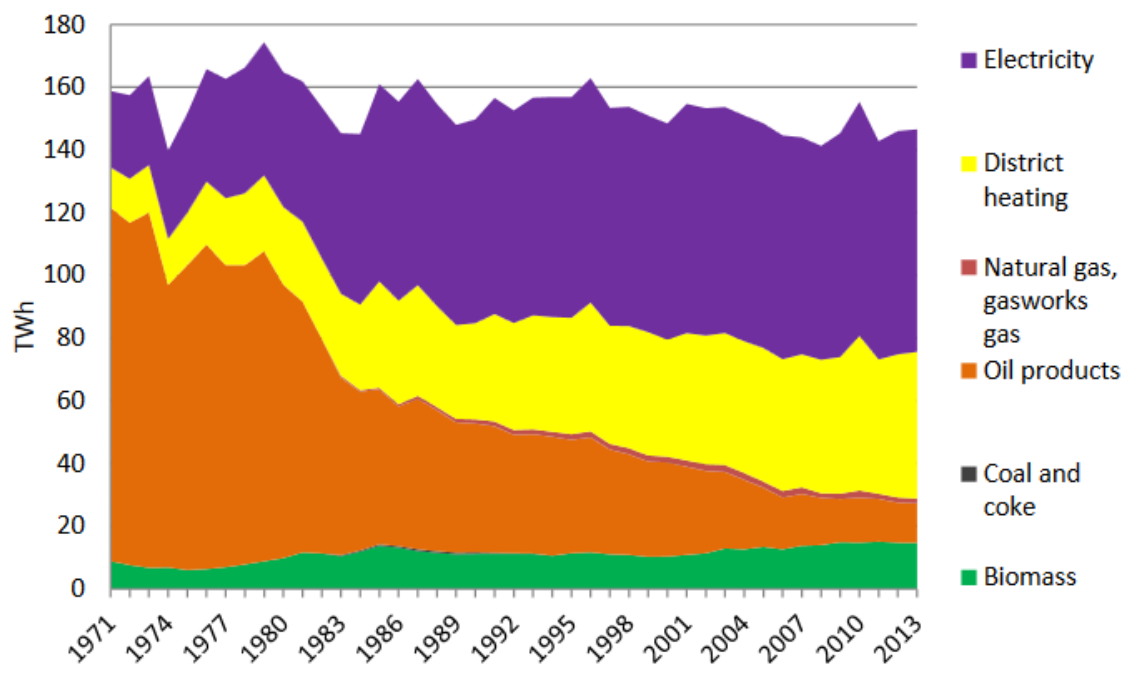

Figure 7. Sweden: Final energy use (in TWh) in residential and services sector by energy carrier for 1971-2013 (Swedish Energy Agency 2015)

However, Figure 8 taken from Energy Commission statistical documents shows a decline in the growth rates of electricity generation projections after 2015 (Energy Commission Malaysia 2017). The forecasts imply reduced growth rate in general that can be due to one or a combination of several factors (Sovacool 2010) such as increasing energy use efficiency; structural changes in economic activities, e.g., from energy-intensive 
manufacturing to less energy-intensive service-based industries; declining overall economic development; or demand-side management initiatives, which have yet to be implemented consistently in Malaysia (Economic Planning Unit, 2018a). The projections by Energy Commission have correctly considered the declining growth rates that are in part due to energy efficiency and conservation especially by large consumers through initiatives such as smart buildings and high technology or high-efficiency appliances (e.g., chillers). Nevertheless, these projections do not indicate any reduction in the demand, only a declining growth rate.

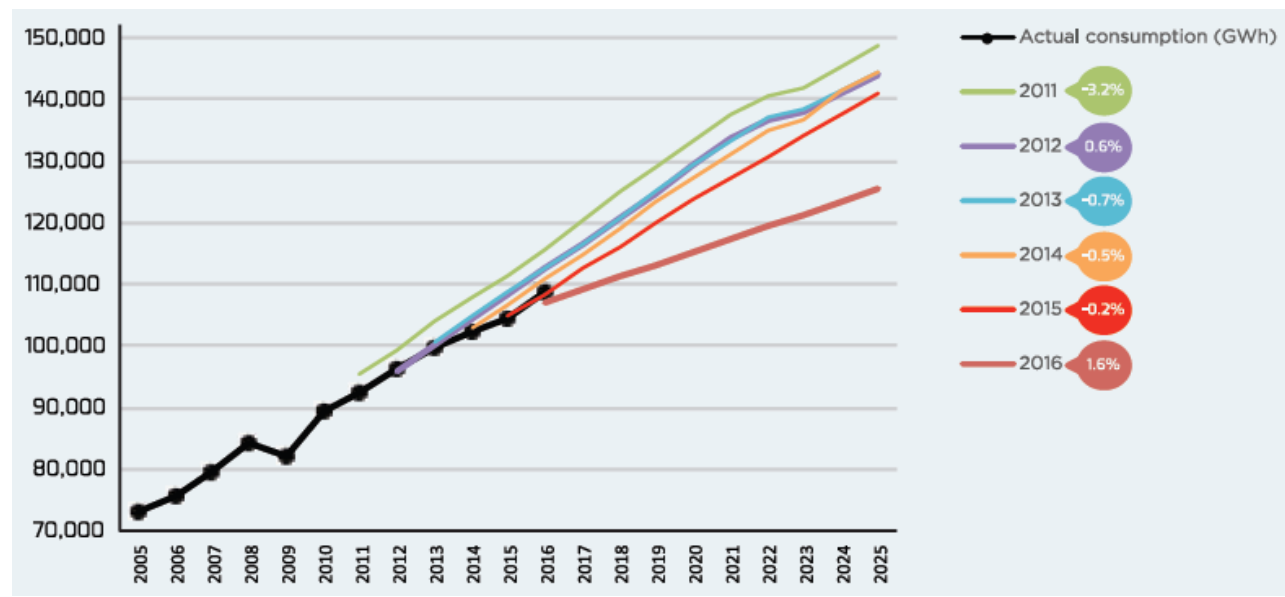

Figure 8. Official statistics by Malaysian Energy Commission on forecast versus actual electricity consumption (in GWh) (Energy Commission Malaysia 2017)

Table 2. Current and projected capacities of renewable energy resources for Malaysia (SEDA 2018; 2019)

\begin{tabular}{|c|c|c|c|c|c|}
\hline \multirow{2}{*}{ Technology } & \multirow{2}{*}{$\begin{array}{l}\text { Approved Capacity } \\
\text { Up to } 2020 \text { (MW) }\end{array}$} & \multirow{2}{*}{$\begin{array}{l}\text { Installed Capacity } \\
\text { Up to } 2020 \text { (MW) }\end{array}$} & \multicolumn{2}{|c|}{$\begin{array}{l}\text { Potential Additional } \\
\text { Capacity (MW) }\end{array}$} & \multirow{2}{*}{$\begin{array}{c}\text { Total Capacity } \\
\text { Up to } 2025 \text { (MW) }\end{array}$} \\
\hline & & & $\begin{array}{c}\text { Tendered } \\
\text { (Up to 2022) }\end{array}$ & $\begin{array}{c}\text { Planned } \\
\text { (Up to 2025) }\end{array}$ & \\
\hline \multicolumn{6}{|l|}{ Solar PV } \\
\hline PV Farm (FiT) & 330.16 & 5.14 & n.r. & n.r. & $335 \cdot 30$ \\
\hline Rooftop (FiT) & 98.43 & 9.32 & n.r. & n.r. & 107.75 \\
\hline LSS/USS & 1500 & 34.5 & 500 & 230 & 2000 \\
\hline NEM & 34.53 & 9.877 & 500 & 462 & 1006.407 \\
\hline SelCo & n.r. & n.r. & n.r. & n.r. & n.r. \\
\hline Biomass & 396.19 & 55.00 & 12.40 & o & 463.59 \\
\hline Biogas & 220.86 & 20.14 & O & O & 241.00 \\
\hline Small hydro & 538.48 & 30.30 & 41.70 & 32.84 & 643.32 \\
\hline Waste to energy* & 104.42 & $13 \cdot 36$ & 30.00 & o & 147.78 \\
\hline
\end{tabular}

Notes: *Includes landfill, agriculture waste, solid waste; n.r. = not reported

\section{Role of Solar Photovoltaic}

Malaysia adopts a 25\% reserve margin principle of generation capacity over maximum demand. This means for a nominal maximum demand of $17.0 \mathrm{GW}$ for Peninsular
Malaysia; the total generation capacity needs to be about 21.3 GW.

For a pre-year 2020 scenario projection, a target cumulative solar PV systems of $3.0 \mathrm{GWp}$ of installed capacity can reduce maximum demand from conventional 
electricity generation by approximately $2.4 \mathrm{GW}$ based on the actual on-site maximum generation of about $80 \%$ of the nominal capacity due to ambient thermal effect (Nelson, 2011).

For a post-2020 scenario, it is estimated that by installing about 5.0GWp of solar PV systems capacity, we can reduce maximum demand by about $4.0 \mathrm{GW}$ from $23.5 \mathrm{GW}$ to 19.5GW as based on empirical data trends in Figure 9 applied to Energy Commission data for 2017 projected to 2035 (Energy Commission Malaysia 2017). This strategy can reduce the generation capacity needed (i.e., including a $25 \%$ reserve margin) to $24.4 \mathrm{GW}$ (i.e., 1.25 times $19.5 \mathrm{GW}$ ) instead of $29.4 \mathrm{GW}$ (i.e., 1.25 times 23.5GW). Based on similar assumptions, doubling the installation of solar PV capacity to $10.0 \mathrm{GWp}$ can reduce maximum demand by about 8.oGW based on the Outlook 2017 projection, i.e., from $23.5 \mathrm{GW}$ to $15.5 \mathrm{GW}$ in 2035 . This reduction is realistic if it is equal to or higher than the trough demand during the off-peak consumption. The detailed calculations for the projections are available in the Appendix.

The maximum power demand can be further reduced through energy efficiency measures. A preliminary study on demand-side management (DSM) by the Malaysian Economic Planning Unit (2018b) estimates a demand saving of $3.315 \mathrm{GW}$ is expected to accrue over the entire DSM program duration up to 2030.

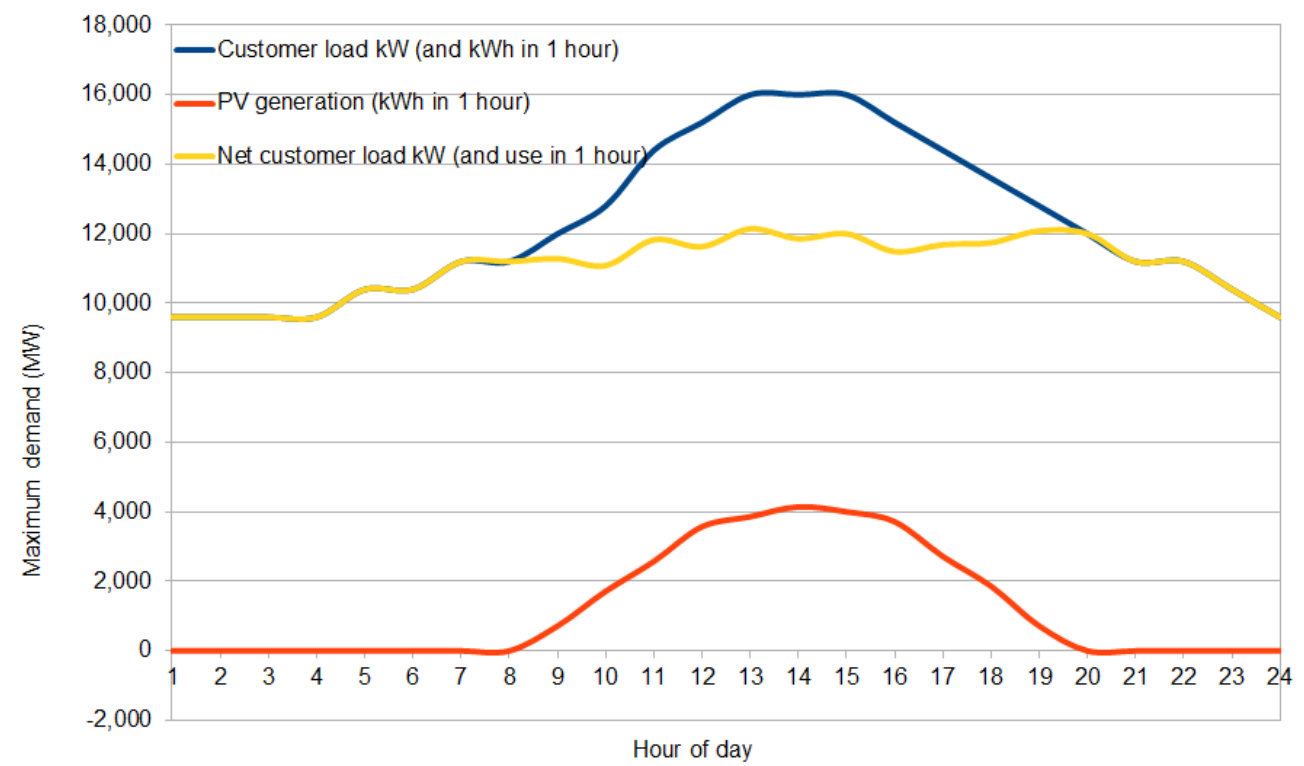

Figure 9. Peninsular Malaysia: Impact of solar photovoltaic (PV) generation on maximum demand.

\section{Role of Energy Efficiency and Conservation}

Energy efficiency and conservation (EE\&C) serves to reduce the total electricity demand, thereby increasing the relative proportion of renewable energy contribution. Thus EE\&C is a contributory component to enhance the relative share of renewable energy in the national electricity mix. To illustrate, in the preceding projection in Section III(C) in which solar PV can potentially reduce maximum demand by 8.oGW, the resultant proportion of renewable energy will be higher.
By the relatively low investment required for their implementation, EE\&C measures are touted as low-hanging fruits relative to the benefits offered. Further, the initiatives encourage local participation and ensure community resilience as they are largely carried out locally. Table 3 summarises the advantages or benefits alongside several energy efficiencies and conservation initiatives that have been undertaken (Lalchand 2012; Chin et al., 2013).

Most commercial and some industrial users have significant air-conditioning cooling loads. The efficiency of new large centralised chiller technology has improved compared to that found in older plants. One of the author's experiences from energy audits for some commercial 
consumers show their air conditioning energy use share at 50 to $60 \%$ and lighting energy use share at up to $30 \%$. The share of air conditioning and lighting energy use for industries are not as well known, but they may be of the conservative order of about $10 \%$ of their respective total consumption (KeTTHA 2009). The calculation details for the estimated saving is given in the Appendix.

Table 3. Advantages or benefits and initiatives to promote energy efficiency and conservation in Malaysia

\begin{tabular}{|c|c|}
\hline Advantages/Benefits & Initiatives \\
\hline $\begin{array}{l}\text { - Energy cost savings for air conditioning and lighting } \\
\text { in commercial buildings and industries by better } \\
\text { insulation } \\
\text { - Tax benefits for companies under Investment Tax } \\
\text { Allowance (e.g., for replacing centralised chillers with } \\
\text { newer efficient ones) } \\
\text { - Encourage local participation and ensure community } \\
\text { resilience as they are largely carried out locally }\end{array}$ & $\begin{array}{l}\text { - Implement cogeneration and trigeneration of power } \\
\text { and heating and cooling duties to reduce efficiency } \\
\text { losses in transmission and distribution of electric } \\
\text { power } \\
\text { - Replace commonly used tubular T8 fluorescent lamps } \\
\text { for commercial and residential use with more efficient } \\
\text { LED alternatives that give the same lighting level but } \\
\text { at about two-thirds of the energy consumed } \\
\text { - Use 5-star energy efficient refrigerators-KeTTHA has } \\
\text { promoted them under its Sustainability Achieved Via } \\
\text { Energy Efficiency (SAVE) program since 2011 } \\
\text { - Replace window or split type air-conditioners with the } \\
\text { 5-star or inverter type equivalent models-also } \\
\text { applicable to other home appliances such as televisions } \\
\text { and fans } \\
\text { Install and enhance insulation for roof, wall, and } \\
\text { window to help reduce cooling power demand }\end{array}$ \\
\hline
\end{tabular}

Thus, it is cost-effective to replace older chillers to benefit from the higher efficiency of new chillers due to current electricity tariffs and their anticipated increase in line with the government's declaration to remove fuel subsidies gradually. This suggestion is more so since such companies can avail tax benefits (Investment Tax Allowance, ITA) that the government has provided for the adoption of energy efficiency and conservation initiatives. Replacing every ton of refrigeration of centralised chiller plant with more efficient plant can offer energy cost saving on the order of about RM528 per annum (based on an estimated saving of $0.5 \mathrm{~kW}$ per ton of refrigeration on an average operation of 10 hours per day and 22 days per month at average tariff of $0.40 \mathrm{RM} / \mathrm{kWh}$ ) for typical users such as offices, shopping malls, and hospitals.

To illustrate the magnitude of potential energy saving, we consider Malaysian statistics for 2015 that reports commercial and industrial electricity use to be $36,645 \mathrm{GWh}$ and 43,754GWh, respectively (Malaysia et al., 2015). Thus, a conservative energy demand saving an estimate of only $10 \%$ for the cooling load equates to about $1,832 \mathrm{GWh}$ saving for commercial users and $438 \mathrm{GWh}$ for that of industrial consumers, making a total saving of about 2,270GWh per annum. This energy saving implies a demand saving of about 370MW, hence avoiding a need for power generation capacity of about $463 \mathrm{MW}$ (including a $25 \%$ reserve margin). Based on one of the author's experience (during his involvement in the design of the LEO (Low Energy Office) building for the then Ministry of Energy, Green Technology, and Water (KeTTHA) in Putrajaya), the actual saving from replacing old chillers with state-of-the-art energy efficient chillers can be as much as $25 \%$ without sacrificing the cooling capability required, which gives a correspondingly higher reduction in maximum demand and generation 
capacity need.

Similarly, energy efficient lighting for commercial and industrial users would provide additional saving. Based on shares of energy used of $20 \%$ for commercial and $10 \%$ for industrial users, and conservative prospective saving to be achieved of about $48 \%$ (up to 50\%) for T8 fluorescent tubes replaced with LED, changing existing lighting to the latter more efficient alternative can save $1173 \mathrm{GWh}$ a year. Further, there can be additional saving for air-conditioning due to a lighting energy saving of about $20 \%$, which equals to 235GWh. Thus the combined lighting and air-conditioning energy saving would equate to a demand saving of about 229MW, implying a reduction in power generation capacity required of about $287 \mathrm{MW}$.

The total potential energy saving from using energy efficient lighting and replacing existing older centralised chillers with new more efficient units can be as much as $3677 \mathrm{GWh}$, which would equate to a demand reduction of 6ooMW. Allowing for a $25 \%$ reserve margin, this would equate to a reduction in required power generation capacity of $750 \mathrm{MW}$.

Energy-efficient air-conditioners can contribute an annual saving of $76.65 \mathrm{GWh}$ per year up to a total potential saving of 919.8GWh. This estimate is made by assuming 1 million units are changed (or installed) annually with 20\% (i.e., 200,000 units) being the energy-efficient 5-star airconditioners over a 12-year period (thus giving a total replacement of 2.4 million out of 12 million units) with a conservative $25 \%$ energy saving for an average daily use of 6 hours at $70 \%$ utilisation factor. Carrying out such replacement of domestic air-conditioners can reduce demand by $975 \mathrm{MW}$ and power generation capacity by 1.219 GW.

Table 4 Summarises the estimated annual saving in terms of energy, cost, and capacity from these initiatives, which amounts to a total on the order of 3,181 MW corresponding to $13,604 \mathrm{GWh}$ per year with a cost saving of RM16.o billion.

Table 4. Estimated annual saving through representative energy-efficient device replacement initiatives

\begin{tabular}{|l|c|c|c|}
\hline \multicolumn{1}{|c|}{$\begin{array}{c}\text { Energy-Efficient Device } \\
\text { Replacement Initiative }\end{array}$} & $\begin{array}{c}\text { Electricity Saving } \\
\text { (GWh/year) }\end{array}$ & $\begin{array}{c}\text { Cost Saving } \\
\text { (RM) }\end{array}$ & $\begin{array}{c}\text { Demand Reduction } \\
\text { (MW) }\end{array}$ \\
\hline Chilling in industrial and commercial sectors & 2,270 & 9.08 billion & 370 \\
\hline Lighting in industrial and commercial sectors & 11,257 & 4.50 billion & 1,836 \\
\hline Air conditioning in the residential sector & 76.65 & 2.39 billion & 975 \\
\hline Total Saving & 13,604 & 16.0 billion & 3,181 \\
\hline
\end{tabular}

\section{NATIONAL-LEVEL INITIATIVES FOR RENEWABLE ENERGY DEVELOPMENT}

Since the middle of the 2000, several efforts have been undertaken nationwide to spur the development and uptake of renewable energy in Malaysia (Chua et al., 2010; Oh et al., 2010). Two such initiatives are delineated, namely developing a national solar energy industry and producing biogas through methane emissions recovery from the palm oil mill effluent (POME) treatment process.

\section{A. Development of National Solar Energy Industry}

\section{Progress and status}

Malaysia has established grounds in the solar photovoltaic manufacturing industry since First Solar; a USA-based company began its operations in Malaysia in 2007 with four manufacturing lines in Kulim. The initiative continued with the Malaysia Building Integrated Photovoltaic (MBIPV, 2005-2011) project administered by the Malaysian Ministry of Energy, Green Technology and Water (KeTTHA) and supported by the Global Environment Facility (GEF) through the United Nations Development Programme (UNDP) (Haris et al., 2009). The industry has expanded to 
become a major economic development sector with international market reach (Academy of Sciences Malaysia 2010). After First Solar, several other international companies have set up solar PV manufacturing facilities in Malaysia such as SunPower (USA) (SunPower Corporation 2014) and Hanwa Q Cells (Germany) (Hanwa Q Cells $\mathrm{GmBH}$ 2014).

The ongoing Net Energy Metering (NEM) scheme allows industrial, commercial, and residential consumers to install rooftop solar PV systems for self-consumption and for the excess electricity to be exported to the national grid at a set selling rate or displaced cost. However, the overall response has been dismal (Joshi, 2018). The TNB-declared displaced cost is fixed at 31 cent/kWh for low voltage connection but only 23 cent/kWh for medium voltage connection, which is lower than the current average generation cost of 26.39 cent/kWh (see Figure 10 for a delineation of the tariff cost structure), thus disincentives the NEM scheme (Energy Commission Malaysia 2016a). As mentioned earlier in Section II, this deficiency has since been addressed through an announcement in October 2018 to offer a selling rate equal to the tariff rate (Yeo 2018). Further as has also been stated, under the $11^{\text {th }}$ Malaysia Plan, ST has continued to pursue establishing a national solar energy generation industry by approving contract awards to implement solar PV projects of the order of 30 to 50MW per plant size through the LSS/USS program starting in 2017 (see Table 5 for details of the awarded generating capacity). The target is to achieve a total capacity of $1000 \mathrm{MW}$ by 2020 or $250 \mathrm{MW}$ per year on average (SEDA 2017).

Table 5. Malaysia: Large scale solar (LSS)/Utility scale solar (USS) project contracts awarded

\begin{tabular}{|l|c|c|c|c|c|}
\hline Award Round & $\begin{array}{c}\text { Commercial } \\
\text { Operation Year }\end{array}$ & $\begin{array}{c}\text { Peninsular } \\
\text { Malaysia }\end{array}$ & $\begin{array}{c}\text { Sabah (and } \\
\text { Labuan) }\end{array}$ & $\begin{array}{c}\text { Total } \\
\text { Projects }\end{array}$ & $\begin{array}{c}\text { Total Capacity } \\
\text { (MW) }\end{array}$ \\
\hline Cycle 1 & $2017 / 2018$ & 383.996 & 16.9 & 18 & 400.896 \\
\hline Cycle 2 & $2019 / 2020$ & 506.388 & 50.6 & 40 & 556.988 \\
\hline Cycle 3 & $2021 / 2022$ & 220 & 50 & 6 & 270 \\
\hline & Total & 1110.384 & 117.5 & 66 & 1227.884 \\
\hline
\end{tabular}

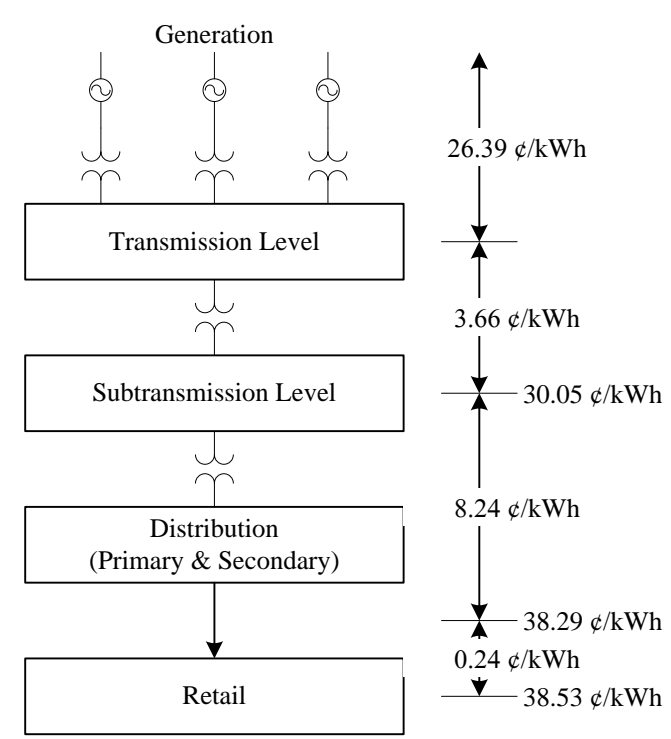

Figure 10. Electricity base tariff components and their associated costs as implemented under the Malaysian Government's incentive-based regulation (IBR) framework (Energy Commission Malaysia 2016d)

\section{Advantages and benefits}

The creation of a large scale national solar PV industry has realized the following advantages and benefits to the nation: setting up a new technology sector with high growth potential that creates thousands of job opportunities, establishing Malaysia as a world-leading solar PV equipment manufacturer using imported technology, generating revenues with direct returns for reinvestment for the industry and contribution to national gross domestic product (GDP), and providing direct benefits to local industries that form part of the value chain (Academy of Sciences Malaysia 2010).

\section{Technical and commercial challenges}

Several supporting governmental strategies have been implemented to build a national solar PV industry, namely 
by nurturing a conducive market environment, enhancing industry participation, building the required infrastructure, and promoting research, development, and innovation. These initiatives are summarised in Table 6. Further efforts to ensure a sustainable national solar PV industry necessitate the need to address the management of 2017).

Table 6. Supporting governmental strategies to build a national solar PV industry in Malaysia

\begin{tabular}{|c|c|}
\hline Strategy & Plan \\
\hline $\begin{array}{l}\text { Nurture a conducive market } \\
\text { environment }\end{array}$ & $\begin{array}{l}\text { - Promote public awareness and implement advocacy programs } \\
\text { - Install solar PV systems in government buildings and promote Green Building } \\
\text { Index (GBI) compliance } \\
\text { - Design a long-term national energy policy based on renewable energy particularly } \\
\text { solar PV }\end{array}$ \\
\hline $\begin{array}{l}\text { Enhance industry } \\
\text { participation }\end{array}$ & $\begin{array}{l}\text { - Intensify human capital development through industry missions, sponsored } \\
\text { exchange programs such as apprenticeships, and training abroad } \\
\text { - Facilitate partnerships between multinational companies and local industries } \\
\text { - Upgrade targeted local industries to solar PV-related activities (e.g., wafer } \\
\text { fabrication in the electronics industry) to leverage on lower costs, lower entry } \\
\text { levels, and faster implementation } \\
\text { - Introduce industry demonstration and quality programs and award schemes }\end{array}$ \\
\hline frastructure & $\begin{array}{l}\text { - Introduce business facilitation packages, e.g., soft loan schemes and focus grants } \\
\text { for local industries to enter and expand } \\
\text { - Promote intellectual property acquisition and foreign direct investments with a } \\
\text { focus on direct benefits for local industries to trigger domestic direct investments } \\
\text { - Identify government or government-linked company (GLC) investments in new } \\
\text { promising solar PV technologies and catalyse development, incubation, and } \\
\text { creation of fast spin-off companies }\end{array}$ \\
\hline $\begin{array}{l}\text { Promote research, } \\
\text { development, and innovation }\end{array}$ & $\begin{array}{l}\text { - Design and implement a national solar PV research and development (R\&D) } \\
\text { roadmap with a focus on technology innovation and cost reduction } \\
\text { - Establish internationally-certified test facilities and solar PV R\&D centre to } \\
\text { support required activities } \\
\text { - Increase R\&D budget for technology and process development with constant } \\
\text { industrial monitoring and feedback } \\
\text { - Establish review and an advisory committee comprising local and international } \\
\text { experts } \\
\text { - Enhance collaboration between industry and academia } \\
\text { Exploit the Brain Gain Malaysia program with a special focus on solar PV } \\
\text { technology } \\
\text { Foster growth of technopreneurs }\end{array}$ \\
\hline
\end{tabular}




\section{B. Methane Recovery and Biogas Production from Palm Oil Mill Effluent Treatment}

\section{Progress and status}

It is now mandated for all palm oil mills to recover or avoid methane gas emissions in treating the wastewater discharge of palm oil mill effluent (POME) to meet regulatory discharge limits. There is potential to use the methane for electricity and heat generation subject to appropriate treatment and upgrade to suitable quality as biogas (Wu et al., 2010).

The Malaysian Government's Economic Transformation Programme (ETP) under Entry Point Project $5\left(\mathrm{EPP}_{5}\right)$ requires palm oil mills to install facilities to generate biogas or avoid methane emissions by 2020 (PEMANDU 2010). The biogas can be used internally within a mill through cofiring with biomass or replacing the fuel in a boiler to generate steam and chilled water. In the former approach, there is an opportunity to use fewer biomass sources such as oil palm mesocarp fibres and make them available for other downstream higher value uses. Another possibility is to supply the captured biogas to local communities through pipelines or in bottles (Malaysian Industry-Government Group for High Technology (MIGHT) 2013). A mill can also supply the biogas-generated electricity to the national grid to get additional income under the Feed-in-Tariff scheme (SEDA (Sustainable Energy Development Authority of Malaysia) 2012). As of July 2017, biogas plants have been constructed at 94 mills in Malaysia with another eight facilities under construction while 144 sites are under such planning (Astimar et al., 2017).

\section{Advantages and benefits}

Trapped biogas from palm oil milling sector to be used as an energy source can potentially avoid about 17 million tonnes (Mt) $\left(1.7 \times 10^{7}\right)$ of $\mathrm{CO}_{2}$ equivalent $\left(\mathrm{CO}_{2} \mathrm{e}\right)$ (Astimar et al., 2017). In particular, unrecovered methane emissions from POME that escape to the atmosphere may contribute towards greater global warming and climate change, because methane is a more potent greenhouse gas that has 72 times the global warming potential of $\mathrm{CO}_{2}$ measured over 20 years and 21 to 25 times over 100 years. This problem has been exacerbated by an increasing number of palm oil mills in Malaysia from just about 10 mills in 1960 to 454 operating mills in 2017 (Malaysian Palm Oil Board 2018), and oil palm has the largest agricultural plantation acreage and production in the country compared with other major crops (Department of Statistics Malaysia 2017).

A life cycle assessment study on Malaysian palm oil milling reveals that uncaptured methane emissions from POME contributes the highest environmental impact towards climate change in the country and is responsible in making the overall industry, not environmental friendly (Subramaniam et al., 2008). The unrecovered and unutilised methane-rich biogas from the aerobic decomposition of the POME wastewater treatment process has also been highlighted in a post-evaluation of the BioGen project (Aldover et al., 2010). Additionally, the potential revenue from generating bioenergy may be used to offset POME treatment cost. Based on the reported amount of oil palm fresh fruit bunch processed in 2015, an estimated $548 \mathrm{MW}$ of electricity can potentially be generated (assuming power output at 40\%) (Astimar et al., 2017).

\section{Technical and commercial challenges}

By 2020, it is not allowed by regulations to treat POME in Malaysian palm oil mills through the current conventional way of using open ponds or lagoons (i.e., open digesting tanks) because valuable biomethane is released to the atmosphere in such systems besides being a GHG emission source (Loh et al., 2017). An alternative to converting the bulk of POME to biomethane is to use a closed anaerobic digester system in the first treatment stage to handle the high organic matters in the wastes. A covered lagoon system can be installed directly and cost-effectively using floating plastic membranes on open ponds; in that way, the released biomethane is captured and retained within the floating covers (Lam et al., 2011). Such a biogas capture system has been applied in Malaysia in flaring, as boiler fuel in power and heat generation, and as feedstock in hydrogen production (Tong et al., 2004; 2005; NOVAVIRO Technology Sdn Bhd 2010). Moving forward, we can employ 
high-rate anaerobic digesting tank systems for optimal biogas generation to produce electricity (Najafpour et al., 2006; Poh et al., 2009; Ahmed et al., 2015). However, to benefit from the FiT scheme incentive by connecting to the national electricity grid, a constraint is the remote location of most mills. In this regard, we advocate implementing a smart grid for renewable resources remote from the national grid (Electric Power Research Institute (EPRI) 2008). An example pertains to mills in Sabah, in which it is expected to be costlier to subsidise diesel generation than to put up a smart grid interconnection to a few such mills.

\section{EMERGING RENEWABLE ENERGY OPTIONS FOR ELECTRICITY GENERATION IN MALAYSLA}

Several electricity generation alternatives from low carbon energy options are available or currently considered under various development stages in Malaysia. They include the following (in no particular order): small hydroelectricity (Table 7), fuels and electricity from oil palm biomass, municipal solid waste decomposition (Table 9), thoriumbased nuclear power (Table 10), ocean thermal energy conversion (OTEC) (Table 11), and hydrogen using fuel cells (Table 12). This section provides an overview of the advantages or benefits within the Malaysian context and delineates several challenges faced for these alternatives. A summary of the potential of these options considered is given in Table 13.

Small scale hydropower stations offer low operating cost besides the reliability of employing a mature technology. A small hydroelectric facility is especially suitable for implementation in locations far away from the main electricity grid that faces difficulty to receive grid-fed power supply (Ong et al., 2011). According to SEDA statistics, there are 60 applications with feed-in tariff approval for small hydropower projects in 2017. The cumulative capacity of 538.48MW of small hydropower projects are in progress under the FiT scheme with a total commissioned installed capacity of $30.30 \mathrm{MW}$ with annual energy generation of 64.6oGWh in 2017 (SEDA 2018). An estimated 490$500 \mathrm{MW}$ of small hydropower is potentially available in
Malaysia by 2020 (KeTTHA 2008a).

Second-generation fuels (such as bio-oil) derived from palm oil biomass offers more advantages at least from an ethical perspective in replacing fossil fuels by obviating competition and conflict with human food supply and animal feed. An estimate indicates the potential of generating 1340MW grid-connected electricity from palm biomass by 2030 (Haris et al., 2009) (Malaysian IndustryGovernment Group for High Technology (MIGHT) 2013). The Malaysian National Innovation Agency (AIM, now nonoperational) has created a biomass processing hub in the East Malaysian state of Sarawak, which is billed as the first of such a facility in Southeast Asia. The hub receives investment from Brooke Renewables, a consortium of international biofuel companies and includes a commercial second-generation bioethanol plant supported by enzyme technology from Beta Renewables, which operates the world's first second-generation bioethanol plant in Italy (Crescentino) (PEMANDU (Performance Management \& Delivery Unit of Malaysian Government) 2013).

Apart from methane recovery from POME, biogas can also be produced from landfills in Malaysia by decomposing municipal solid waste (MSW). The captured landfill gas (LFG) can be upgraded to pipeline-quality gas to produce electricity or directly as fuels for powering homes, factories, buildings, and vehicles. It is easier to design a new and sanitary landfill for LFG utilisation than retrofitting at a later stage as shown through the Bukit Tagar project by KUB-Berjaya Enviro, which operates a 4-MW gas engine to generate electricity and is reported to be in process of connecting a larger capacity to the grid (as of end of 2018) (KUB-Berjaya Enviro 2019). There is potential in harnessing and further developing waste-to-energy options using MSW to produce bioenergy forms in Malaysia (Chien Bong et al., 2017).

As for nuclear energy, addressing its real and perceived dangers is of the utmost importance for its deployment in Malaysia, which may have generated greater concern in light of the Fukushima Daiichi accident in 2011. In this regard, use of thorium as a main fuel cycle for nuclear power shows potential, particularly liquid fluoride thorium reactors (LFTR) as compared to uranium which is the basic material in today's commercial technology. However, the present 
Malaysian political administration helm, which changed after its 2018 general election does not favour nuclear power use (Malaysiakini 2017). Further, nuclear may no longer be considered the cheapest clean power type given the declining production cost of solar and biomass power (SEDA 2017).

Energy from OTEC uses heat from the Sun stored in ocean surface water layers to generate electrical energy or energy products (Jaafar 2015). Although argued to be one of the main potential renewable energy sources in Malaysia (Academy of Sciences Malaysia 2015), the entailed high capital and operating cost remains its biggest challenge to be economically viable. Implementation of OTEC remains to be at a pilot scale such as the $1 \mathrm{MW}$ demonstration unit carried out in Hawaii (Vega, 2010; Jaafar, 2017).

Potential exploitation of geothermal energy resource revolves around the Apas Kiri area in Tawau, Sabah based on data around the year 2008. The discovery of this resource with an electricity generation potential of $67 \mathrm{MW}$ was made by the Minerals and Geoscience Department under the purview of the then Ministry of Natural Resources and Environment. However this initiative led by Tawau Green Energy Sdn. Bhd. reportedly has been abandoned (Editorial of Malay Mail 2018).

Fuel cells using hydrogen has been identified as a national priority research area (especially during 1996 to 2007 with up to RM34 millions of federal grant money) by the then ministry-in-charge (Ministry of Science, Technology, and Innovation (MOSTI), now subsumed under MESTECC). It is noteworthy that hydrogen is an energy carrier, not a primary energy source unless it is generated from non-fossil fuel resources (e.g., via electrolysis of water). On the other hand, fuel cells are not a RE resource by themselves; they are energy conversion mechanisms.

Table 7. Advantages and challenges of power generation from small hydroelectricity

\begin{tabular}{|l|l|}
\hline \multicolumn{1}{|c|}{ Advantage } & \multicolumn{1}{|c|}{ Challenge } \\
\hline - Reliable (mature technology) & $\begin{array}{l}\text { Remote location for connecting to the national } \\
\text { - Loctricity grid to capture advantage given by Fit } \\
\text { scheme } \\
\text { - Low levelized cost of electricity } \\
\text { - Not affected by fossil fuel prices } \\
\text { - No environmental and socioeconomic consequences } \\
\text { - (as compared to large hydropower) } \\
\text { - Also provides flood and irrigation control } \\
\text { - Promotes eco-tourism } \\
\text { alternative to diesel generators for remote villages in } \\
\text { Sabah and Sarawak }\end{array}$ \\
\hline
\end{tabular}

Table 8. Advantages and challenges of energy generation from oil palm biomass

\begin{tabular}{|l|l|}
\hline \multicolumn{1}{|c|}{ Advantage } & \multicolumn{1}{c|}{ Challenge } \\
\hline - The abundance of palm biomass resource & $\bullet$ High capital investment \\
$\begin{array}{l}\text { - Several technologies available for conversion of } \\
\text { biomass to energy }\end{array}$ & $\begin{array}{l}\bullet \text { Inconsistent biomass supply chain } \\
\text { Unattractive electricity tariff for grid-connected }\end{array}$ \\
\hline
\end{tabular}


Table 9. Advantages and challenges of energy generation from municipal solid waste (MSW) landfill gas

\begin{tabular}{|c|c|}
\hline Advantage & Challenge \\
\hline $\begin{array}{l}\text { - Highest methane generator in Malaysia; expected to } \\
\text { rise with more MSW generated due to increased } \\
\text { population and urbanisation besides poor recycling } \\
\text { - Captured biogas can be upgraded to pipeline gas to } \\
\text { generate electricity or as fuels }\end{array}$ & $\begin{array}{l}\text { Heterogeneous feedstock has varying sizes, shapes, and } \\
\text { compositions that need pre-treatment to avoid unsteady } \\
\text { operation and uncertain product quality (in this regard, } \\
\text { refuse-derived fuel as a form of processed MSW form is } \\
\text { not viable because of the high cost) }\end{array}$ \\
\hline
\end{tabular}

Table 10. Advantages and challenges of nuclear energy generation using thorium-based technology (Mathieu, 2006;

Cooper et al., 2011; Forsberg et al., 2011; Schaffer, 2013)

\begin{tabular}{|l|l|}
\hline \multicolumn{1}{|c|}{ Advantage } & \multicolumn{1}{c|}{ Challenge } \\
\hline - Thorium is more abundant in nature than uranium and & $\bullet \begin{array}{l}\text { Significant deviation from current operating } \\
\text { commercial technologies } \\
\text { - Thorium extraction (e.g., in rare earth metals mining), } \\
\text { although complex incurs relatively cheap chemical } \\
\text { separation from its ore impurities } \\
\text { - Low amount of radioactive waste production, storage, } \\
\text { and disposal design and performance }\end{array}$ \\
- Resistance to nuclear weapon proliferation \\
- Higher thermal efficiency and power generation \\
efficiency at less cost
\end{tabular}

Table 11. Advantages and challenges of ocean thermal energy conversion (OTEC) development

\begin{tabular}{|l|c|}
\hline \multicolumn{1}{|c|}{ Advantages } & \multicolumn{1}{c|}{ Challenge } \\
\hline - Generation potential of up to 105 GW of electricity is \\
estimated from harnessing the heat in the water depths \\
of over 700 m off Sabah and Sarawak in East Malaysia \\
$\begin{array}{l}\text { (RM395-495 per watt) of electricity produced for a 1 } \\
\text { MW plant size (Jaafar 2017) }\end{array}$ \\
$\begin{array}{l}\text { government of the South China Sea } \\
\begin{array}{l}\text { Can generate spinoff products that include temperate } \\
\text { foods and produce, marine culture, lithium metal, } \\
\text { mineral water, cosmetics, and health products. }\end{array}\end{array}$ & $\begin{array}{l}\text { (onshore) particularly for the cable } \\
\text { Significant electricity transmission losses due to large }\end{array}$ \\
\hline
\end{tabular}


Table 12. Advantages and challenges of energy generation from hydrogen using fuel cells

\begin{tabular}{|c|c|}
\hline Advantages & Challenges \\
\hline $\begin{array}{l}\text { - A fuel cell is considered the most viable energy } \\
\text { conversion device for hydrogen especially in } \\
\text { transportation } \\
\text { - Certain fuel cell variants (e.g., proton exchange } \\
\text { membrane type) can be coupled with solar PV } \\
\text { (Academy of Sciences Malaysia 2017) }\end{array}$ & $\begin{array}{l}\text { - Low efficiency } \\
\text { - Hydrogen source needs to be renewable to render it as } \\
\text { sustainable } \\
\text { - Safe transportation means to end users }\end{array}$ \\
\hline
\end{tabular}

Table 13. Summary of the potential of emerging renewable energy options considered for electricity generation in Malaysia

\begin{tabular}{|c|c|c|}
\hline Electricity Source & Projected Availability & Remark \\
\hline $\begin{array}{llll}\text { Biomass } & \text { from } & \text { oil } & \text { palm/Palm } \\
\text { biomass } & & & \end{array}$ & $\begin{array}{l}\text { Annual projected biomass } \\
\text { availability (in 2012) }=94.00 \\
\text { million ton (wet weight) (Malaysian } \\
\text { Industry-Government Group for } \\
\text { High Technology (MIGHT) 2013) }\end{array}$ & $\begin{array}{l}\text { Has the potential to provide } 1.3 \mathrm{GW} \\
\text { of electricity but constrained by } \\
\text { other economic uses and assured } \\
\text { availability of feedstock resources }\end{array}$ \\
\hline Geothermal & $\begin{array}{l}79 \text { manifestation areas (61 in } \\
\text { Peninsula, } 8 \text { in Sarawak, } 10 \text { in } \\
\text { Sabah (REEP, 2010) }\end{array}$ & $\begin{array}{l}\text { Minimal resources available and not } \\
\text { cost-economic to explore (further } \\
\text { Malaysia is out of the Ring of Fire) }\end{array}$ \\
\hline Wind, wave, tidal & No official statistics reported & $\begin{array}{l}\text { No resource viably exploitable in the } \\
\text { country }\end{array}$ \\
\hline Hydrogen-based fuel cell & $\begin{array}{l}\text { Power capacity }=20,198 \text { MW } \\
\text { (capacity factor }=0.9 \text { ) and energy } \\
\text { generation } 54.162 \text { GWh (share = } \\
15.7 \% \text { ) by } 2050 \text { with hydrogen } \\
\text { generation contribution by OTEC, } \\
\text { wave, tidal current, solar PV, and } \\
\text { nuclear (based on projection of zero } \\
\text { fossil fuel used for energy } \\
\text { generation by 2050) (Academy of } \\
\text { Sciences Malaysia 2015) }\end{array}$ & $\begin{array}{l}\text { Low efficiency; hydrogen source has } \\
\text { to be renewable to render this as a } \\
\text { plausible option. Economic viability } \\
\text { has yet to be established. }\end{array}$ \\
\hline
\end{tabular}

\section{CONCLUSIONS}

The preceding discussions have considered the potential and practically viable options for Malaysia to aim for low carbon power generation options for the future, and show that it can be achieved to a certain degree. As evidenced through the paper, Malaysia has limited practical RE options to achieve its low-carbon aspirations, with solar PV being the dominant resource, both to help achieve the selfdeclared carbon intensity reduction target of $45 \%$ by 2030 as well as to attain a $20 \%$ non-large-hydroelectricity RE share of generation capacity by 2025, with small hydroelectricity, biomass, biogas, and municipal solid waste contributing smaller shares.

Also, diligent adoption of energy efficiency initiatives and practices is expected to contribute a significant share under the DSM program which is expected to be rolled out with the forthcoming legislation for the Energy Efficiency and Conservation Act in 2019. RE from wind energy, marine RE resources and even geothermal (in Sabah) appear to be not 
available or viable for Malaysia to exploit, while the nuclear option is avoided on safety and political considerations.

Solar PV in its various modes such as rooftop and groundmounted farms built to date and the approved LSS/USS systems form the bulk of RE capacity. Similarly, anticipated greater take-up of NEM and SelCo with the revised true net energy metering as approved with effect from January 2019 can greatly enhance the share of the low carbon RE generation capacity going forward.

Also as mentioned in the paper, the potential to harvest the biomass and biogas generation capacity can be significantly enhanced with the recommendation to develop biomass-biogas grids to encourage and incentivize the exploitation of these resources, especially to build up adequate generation capacity in the east-coast region of Sabah, where generation capacity shortfall has contributed to poor supply reliability. With judicious strategies and costeffective incentivisation, the 20\% RE share can be exceeded by 2025 to enhance national energy security while contributing to the global carbon emissions reduction challenge.

\section{APPENDIX}

\section{A. Energy and Renewable Energy Policies in Malaysia}

Table 14. National-level policies and programs related to renewable energy in Malaysia

\begin{tabular}{|c|c|c|c|}
\hline Period & Policy/Plan & Aim & Achievement/Status \\
\hline 1979 & National Energy Policy & $\begin{array}{l}\text { Address energy supply, utilisation, and } \\
\text { environmental objectives in the long term }\end{array}$ & $\begin{array}{l}\text { Diversified energy supply } \\
\text { sources to non-renewables }\end{array}$ \\
\hline 1981 & $\begin{array}{l}\text { Four-Fuel Diversification } \\
\text { Policy }\end{array}$ & $\begin{array}{l}\text { Avoid overdependence on petroleum as } \\
\text { the main energy supply by an increased } \\
\text { emphasis on gas, hydroelectric, and coal } \\
\text { in power generation mix }\end{array}$ & $\begin{array}{l}\text { Diversified energy supply } \\
\text { sources besides petroleum } \\
\text { especially coal use for power } \\
\text { generation }\end{array}$ \\
\hline $\begin{array}{l}1999- \\
2009\end{array}$ & $\begin{array}{l}\text { Malaysian Industrial } \\
\text { Energy Efficiency } \\
\text { Improvement Project } \\
\text { (MIEEIP) }\end{array}$ & $\begin{array}{l}\text { Remove barriers and build capacity to } \\
\text { improve industrial energy efficiency } \\
\text { through policy, planning, research, and } \\
\text { implementation for } 11 \text { sectors: wood, } \\
\text { food, pulp and paper, rubber, iron and } \\
\text { steel, ceramic, glass, cement, plastics, } \\
\text { textile, and oleochemicals }\end{array}$ & $\begin{array}{l}\text { Developed benchmarks, } \\
\text { equipment rating programs, and } \\
\text { auditing; documented and } \\
\text { disseminated information; } \\
\text { trained local energy service } \\
\text { companies; demonstrated and } \\
\text { implemented technologies }\end{array}$ \\
\hline 2000 & Fifth Fuel Policy & $\begin{array}{l}\text { Recognise renewable fuel sources in } \\
\text { generation mix that includes biomass, } \\
\text { biogas, municipal waste, solar, and mini } \\
\text { (not large) hydroelectricity }\end{array}$ & $\begin{array}{l}\text { Promoted renewable energy } \\
\text { generation and use besides large } \\
\text { hydroelectricity }\end{array}$ \\
\hline 2001 & Energy Commission Act & $\begin{array}{l}\text { Establish Energy Commission (or } \\
\text { Suruhanjaya Tenaga) as a regulator of } \\
\text { electricity and piped gas supply } \\
\text { industries }\end{array}$ & $\begin{array}{l}\text { Established Energy Commission } \\
\text { whose role includes advising the } \\
\text { government on energy efficiency } \\
\text { and renewable energy issues }\end{array}$ \\
\hline $\begin{array}{l}2001- \\
2010\end{array}$ & $\begin{array}{l}\text { Small Renewable Energy } \\
\text { Power (SREP) program }\end{array}$ & $\begin{array}{l}\text { Encourage small private power } \\
\text { generation projects using renewables }\end{array}$ & $\begin{array}{l}\text { Met less than targeted } 5 \% \text { of } \\
\text { renewable electricity supply by } \\
2005\end{array}$ \\
\hline $\begin{array}{l}2002- \\
2010\end{array}$ & $\begin{array}{l}\text { Biomass-based Power } \\
\text { Generation and }\end{array}$ & $\begin{array}{l}\text { Reduce GHG emissions growth rate from } \\
\text { fossil fuel-fired combustion of unused }\end{array}$ & $\begin{array}{l}\text { Finalized Renewable Energy } \\
\text { Power Purchase Agreement }\end{array}$ \\
\hline
\end{tabular}




\begin{tabular}{|c|c|c|c|}
\hline & $\begin{array}{l}\text { Cogeneration in the } \\
\text { Malaysian Palm Oil } \\
\text { Industry (BioGen) }\end{array}$ & $\begin{array}{l}\text { biomass wastes through power } \\
\text { generation and combined heat and power } \\
\text { (CHP); also explores another energy } \\
\text { potential }\end{array}$ & $\begin{array}{l}\text { (REPPA) Pro-forma (precursor } \\
\text { to FiT under SREP); established } \\
\text { business facilities (e.g., one-stop } \\
\text { centre); conducted mill energy } \\
\text { audits and policy and biomass } \\
\text { availability studies }\end{array}$ \\
\hline $\begin{array}{l}2005^{-} \\
2011\end{array}$ & $\begin{array}{l}\text { Malaysia Building } \\
\text { Integrated Photovoltaic } \\
\text { (MBIPV) }\end{array}$ & $\begin{array}{l}\text { - Reduce solar PV technology cost in the } \\
\text { long term by integrating with building } \\
\text { design } \\
\text { - Create sustainable BIPV market } \\
\text { through wide applications }\end{array}$ & $\begin{array}{l}\text { Connected } 45 \cdot 9 \mathrm{MW} \text { to the } \\
\text { national grid (versus Ninth } \\
\text { Malaysia Plan target of } 35 \mathrm{oMW} \text { ) }\end{array}$ \\
\hline 2006 & National Biofuel Policy & $\begin{array}{l}\text { Use environmentally sustainable biofuels } \\
\text { to reduce fossil fuels dependence, exploit } \\
\text { the global economic opportunity, and } \\
\text { stabilise crude palm oil prices }\end{array}$ & $\begin{array}{l}\text { Implemented B5 blend palm- } \\
\text { based biodiesel use countrywide } \\
\text { (see another entry) }\end{array}$ \\
\hline 2009 & $\begin{array}{l}\text { National Green Technology } \\
\text { Policy }\end{array}$ & $\begin{array}{l}\text { Increase capability and capacity in green } \\
\text { technologies to contribute to economic } \\
\text { growth in energy, buildings, water and } \\
\text { waste management, and transport sectors }\end{array}$ & $\begin{array}{l}\text { Set up Green Technology } \\
\text { Financing Scheme (GTFS) } \\
\text { under Pusat Tenaga Malaysia } \\
\text { (later called GreenTech } \\
\text { Corporation); promoted } \\
\text { cogeneration and renewable } \\
\text { energy use in power generation }\end{array}$ \\
\hline $\begin{array}{l}2010- \\
2015\end{array}$ & $\begin{array}{l}\text { New Energy Policy (2013- } \\
\text { 2050) }\end{array}$ & $\begin{array}{l}\text { Enhance energy security in economic, } \\
\text { environmental, and social aspects } \\
\text { through market pricing, energy } \\
\text { efficiency, change management, holistic } \\
\text { governance, and supply-side initiatives }\end{array}$ & $\begin{array}{l}\text { Adopted market-based gas } \\
\text { price; implemented } \\
\text { Sustainability Achieve Via } \\
\text { Energy Efficiency (SAVE) } \\
\text { program by SEDA; developed } \\
\text { marginal natural gas fields; } \\
\text { building PETRONAS RAPID } \\
\text { refinery and petrochemical site }\end{array}$ \\
\hline 2011 & Renewable Energy Act & $\begin{array}{l}\text { Set up SEDA to implement a feed-in- } \\
\text { tariff (FiT) scheme for RE }\end{array}$ & $\begin{array}{l}\text { Implemented FiT system under } \\
\text { SEDA's purview }\end{array}$ \\
\hline 2011 & $\begin{array}{l}\text { National Biomass Strategy } \\
2020\end{array}$ & $\begin{array}{l}\text { Recognise biomass waste use mainly for } \\
\text { high value-added products (especially in } \\
\text { the palm oil industry) }\end{array}$ & $\begin{array}{l}\text { Marketed high-quality solid } \\
\text { fuels of briquette or pellet from } \\
\text { palm biomass waste (empty } \\
\text { fruit bunch) }\end{array}$ \\
\hline $\begin{array}{l}2011- \\
2014\end{array}$ & Biodiesel B5 Program & $\begin{array}{l}\text { Implement palm-based biodiesel (B5 } \\
\text { blend) use countrywide; reduce crude } \\
\text { palm oil local inventory to stabilise its } \\
\text { price }\end{array}$ & $\begin{array}{l}\text { Biodiesel blended locally }= \\
295,451 \text { tonne }(2014) ; \text { total } \\
\text { installed capacity }=2.1 \text { million } \\
\text { tonne }\end{array}$ \\
\hline $\begin{array}{l}2016- \\
2020\end{array}$ & $\begin{array}{l}\text { Demand Side Management } \\
\text { (preliminary study) }\end{array}$ & $\begin{array}{l}\text { Implement demand-side initiatives on } \\
\text { electrical and thermal energy in building, }\end{array}$ & $\begin{array}{l}\text { Increase registered electrical } \\
\text { energy managers and energy }\end{array}$ \\
\hline
\end{tabular}




\begin{tabular}{|c|c|c|c|}
\hline & & $\begin{array}{l}\text { industry, household, and transport } \\
\text { sectors }\end{array}$ & $\begin{array}{l}\text { service companies; implement } \\
\text { energy performance contracting } \\
\text { including to retrofit } 100 \\
\text { government buildings; } \\
\text { introduce an enhanced time of } \\
\text { use electricity tariff (targets are } \\
\text { set to the year 2020) }\end{array}$ \\
\hline $\begin{array}{l}2016- \\
2020\end{array}$ & $\begin{array}{l}\text { Net Energy Metering } \\
\text { (NEM) (and Self- } \\
\text { Consumption (SelCo, } \\
\text { 2017)) }\end{array}$ & $\begin{array}{l}\text { Complement FiT by effecting electricity } \\
\text { self-consumption from solar PV and } \\
\text { allowing excess electricity generated to be } \\
\text { sold to TNB }\end{array}$ & $\begin{array}{l}\text { Award 50oMW quota over } 5 \\
\text { years (annual maximum of } \\
\text { 9oMW for Peninsula and 10MW } \\
\text { for Sabah) }\end{array}$ \\
\hline $\begin{array}{l}2017- \\
2020\end{array}$ & Large Scale Solar (LSS) & $\begin{array}{l}\text { Develop solar PV plants that generate } 1- \\
50 M W \text { electricity }\end{array}$ & $\begin{array}{l}\text { Award projects quota of } \\
\text { 10ooMW over } 4 \text { years (annual } \\
\text { 20oMW for Peninsula and } \\
\text { 10MW for Sabah) }\end{array}$ \\
\hline 2016 & $\begin{array}{l}\text { Biodiesel B7 and B10 } \\
\text { programs }\end{array}$ & $\begin{array}{l}\text { Increase to B7 and B10 biodiesel blends } \\
\text { including for commercial and power } \\
\text { generation use }\end{array}$ & $\begin{array}{l}\text { Field trials for B10 palm } \\
\text { biodiesel (e.g., by MPOB) } \\
\text { showed good engine } \\
\text { performance with no } \\
\text { modification needed }\end{array}$ \\
\hline
\end{tabular}

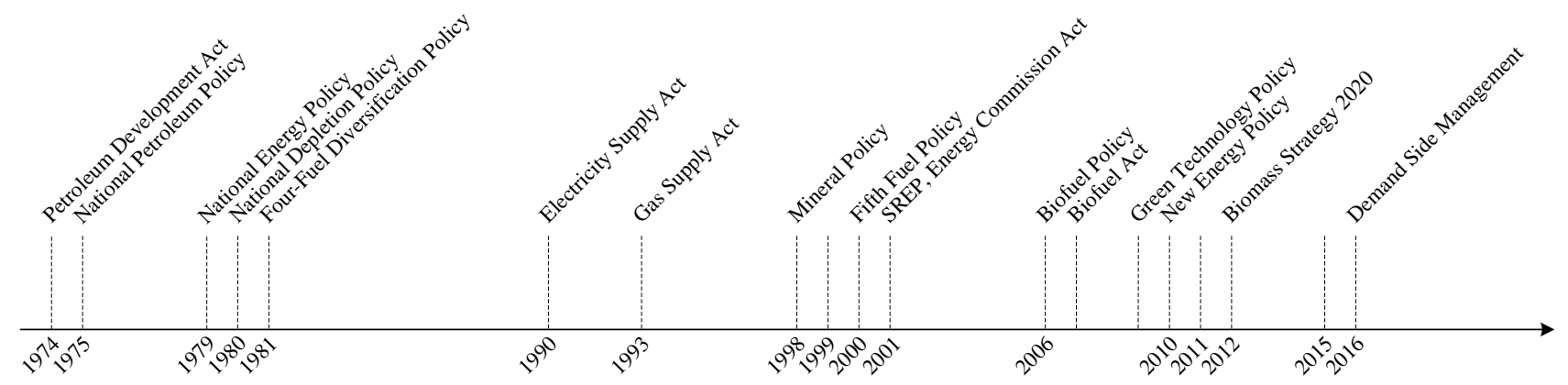

Figure 11. Malaysia: Timeline of energy-related policies and initiatives

\section{B. Energy Efficiency Saving \\ Estimations for Electricity Use in Cooling Load}

The efficiency of older chillers $=1.2 \mathrm{~kW}$ per ton of refrigeration.

The efficiency of newer chillers $=0.7 \mathrm{~kW}$ per ton of refrigeration.

Efficiency gain $=(1.2-0.7)=0.5 \mathrm{~kW}$ per ton of refrigeration .

Annual operating time $=(10$ hour $/$ day $) \times(22$ day $/$ month $) \times(12$ month $/$ year $)=2640$ hour $/$ year.

Annual electricity saving $=(0.5 \mathrm{~kW} /$ ton refrigerant $) \times(2640$ hour $/$ year $)=1320 \mathrm{kWh} /$ ton refrigerant-year

Commercial electricity tariff (average) $=0.40 \mathrm{RM} / \mathrm{kWh}$.

Annual electricity cost saving in commercial sector $=(0.40 \mathrm{RM} / \mathrm{kWh}) \times(1320 \mathrm{kWh} /$ ton refrigerant-year $)=528 \mathrm{RM} /$ ton refrigerant-year 


\section{Energy Efficiency Saving \\ Estimations for Electricity Use in Air Conditioning}

Assumption on user population: 8.0 million domestic

(residential) users, 1.0 million commercial users, o.1 million

industrial users.

Table 15. Energy efficiency saving estimations for electricity use in air conditioning

\begin{tabular}{|l|c|c|c|}
\hline \multicolumn{1}{|c|}{ Sector } & No. of User (in a million) & No. of Unit Per User & Total No. of Unit (in a million) \\
\hline Domestic & 8.0 (household) & $40 \%$ with 3 unit & $9.6(8.0 \square$ o.4 $\square$ 3) \\
\hline Commercial & 1.0 & 5 unit & 5.0 \\
\hline Industrial & 0.1 & 2 unit & 14.8 \\
\hline & & Total $=$ & 0.2 \\
\hline
\end{tabular}

Assumption: 20\% energy-efficient 5-star air-conditioners, 80\% older 3-star refrigerators.

Total no. of air-conditioners to be replaced $=80 \% \times(14.8$ million $)=12$ million units.

The assumption on air-conditioners replacement rate: 1 million unit/year over the next 12 years.

Assumption: $20 \%$ of replaced air-conditioners are 5-star split wall mounted units.

Number of energy efficient units installed annually $=20 \% \times(1$ million $)=200,000$ units.

Assumption on air-conditioners use: 6 hours/day at $70 \%$ utilisation factor (i.e., operating load factor $=0.7)=>(0.7) \times(6$

$\mathrm{h} / \mathrm{d})=4.2 \mathrm{kWh} / \mathrm{day}$.

Daily energy saving per unit $=25 \% \times(4.2 \mathrm{kWh} /$ day $)=1.05 \mathrm{kWh} /$ day.

Annual energy saving per unit $=(0.42 \mathrm{kWh} /$ day-unit $) \times(365$ day $/$ year $)=383.3 \mathrm{kWh} /$ year-unit .

Total annual energy saving $=(383.3 \mathrm{kWh} /$ year-unit $) \times(200,000 \mathrm{unit})=76.65 \mathrm{GWh} /$ year .

Cumulative energy saving over replacement period $=(76.65 \mathrm{GWh} /$ year $) \times \sum_{Y \text { ear }=1}^{12}$ Year $=5979 \mathrm{TWh}$.

\section{Energy Efficiency Saving Estimations for Electricity Use in Lighting}

Table 16. Energy efficiency saving estimations for electricity use in lighting

\begin{tabular}{|l|c|c|c|c|}
\hline & $\begin{array}{c}\text { Nominal Load } \\
\text { (W/tube) }\end{array}$ & $\begin{array}{c}\text { Actual Load } \\
(\mathrm{W} / \text { tube })\end{array}$ & $\begin{array}{c}\text { Energy Saving versus LED } \\
\text { (W/tube) }\end{array}$ & $\begin{array}{c}\text { Energy Saving Ratio for } \\
\text { LED Replacement (\%) }\end{array}$ \\
\hline Fluorescent T8 & 36 & 42 & $20(42-22)$ & 48 \\
\hline Fluorescent T5 & 28 & 30 & $8(30-22)$ & - \\
\hline LED Tube & 18 & 22 & - & 27 \\
\hline
\end{tabular}

The following calculations are based on Energy Commission Malaysia (2015b) data for the year 2015 as applied to the commercial sector.

Lighting share of annual electricity used $=20 \% \times(36,645 \mathrm{GWh})=7329 \mathrm{GWh}$.

Assumption on electricity use: 60\% T5, 20\% LED, and 20\% other lamp types (e.g., compact fluorescent tubes).

Annual electricity use for $\mathrm{T} 5$ tube $=60 \% \times(7329 \mathrm{GWh})=4397 \mathrm{GWh}$.

Annual energy saving if $\mathrm{T}_{5}$ is replaced by LED (after 4 years $)=27 \% \times(4397 \mathrm{GWh})=1173 \mathrm{GWh}$. 
Assumption: Air-conditioning coefficient of performance $=5.0$.

Additional saving from air-conditioning $=(1 / 5.0) \times(1173 \mathrm{GWh})=235 \mathrm{GWh}$.

Cumulative energy saving due to lighting efficiency (after 12 years) $=(9381+1876) \mathrm{GWh}=11,257 \mathrm{GWh}$.

Assumption: Load factor for commercial use $=40 \%$; reserve margin $=25 \%$.

Electricity demand saving $=(11,257 \mathrm{GWh}) /(40 \% \times(8760 \mathrm{~h} /$ year $))=1836 \mathrm{MW}$.

Generation capacity saving (reduction) $=(1836 \mathrm{MW}) \times 125 \%=2295 \mathrm{MW}$.

A similar procedure can be applied to the industrial sector. The total saving from both sectors gives the estimates reported in the main text of the paper.

\section{REFERENCES}

[1] Abdul Malek, B 2010, Renewable Energy (RE) Policy \& Action Plan, Ministry of Energy, Green Technology and Water, Malaysia.

[2] Academy of Sciences Malaysia 2010, A Mega Science Framework for Sustained National Development 2011-2030: The Energy Sector, Academy of Sciences Malaysia, Malaysia.

[3] Academy of Sciences Malaysia 2015, Carbon Free Energy: Roadmap for Malaysia, Academy of Sciences Malaysia, Malaysia.

[4] Academy of Sciences Malaysia 2017, The Blueprint for Fuel Cell Industries in Malaysia, Academy of Sciences Malaysia, Malaysia.

[5] Ahmad, S, Kadir, M, Shafie, S 2011, 'Current perspective of the renewable energy development in Malaysia', Renewable and Sustainable Energy Reviews, vol. 15, pp. 897-904.

[6] Ahmad, S, Tahar, RM 2014, 'Selection of renewable energy sources for sustainable development of electricity generation system using analytic hierarchy process: A case of Malaysia', Renewable Energy, vol. 63, pp. 458-466. https://doi.org/10.1016/j.renene.2013.10.001.

[7] Ahmed, Y, Yaakob, Z, Akhtar, P, Sopian, K 2015, 'Production of biogas and performance evaluation of existing treatment processes in palm oil mill effluent (POME)', Renewable and Sustainable Energy Reviews, vol. 42, pp. 1260-1278. https://doi.org/10.1016/j.rser.2014.10.073.

[8] Aldover, RZ, Hun-Yang, S 2010, Malaysia: Biomass-based Power Generation and Cogeneration in the Palm Oil Industry (BioGen) Project - Phase I: Final Evaluation Report, (MAL/o1/G31).

[9] Astimar, AA, WS, L, AB, N, SK, L 2017, Renewable Energy and Oil Palm Biomass. In Palm Oil Familiarisation Programme, Malaysian Palm Oil Board, Putrajaya, Malaysia.

[10] Basri, NA, Ramli, AT, Aliyu, AS 2015, 'Malaysia energy strategy towards sustainability: A panoramic overview of the benefits and challenges', Renewable and Sustainable Energy Reviews, vol. 42 pp. 1094-1105. https://doi.org/10.1016/j.rser.2014.10.056.

[11] Bong, CPC, Ho, WS, Hashim, H, Lim, JS, Ho, CS, Peng Tan, WS, Lee, CT 2017, 'Review on the renewable energy and solid waste management policies towards biogas development in Malaysia', Renewable and Sustainable Energy Reviews, vol. 
70 ,

pp.

988-998.

https://doi.org/10.1016/j.rser.2016.12.004.

[12] Chin, D, Lalchand, G, Khor, CS 2013, Sustainable Energy Options for Electric Power Generation in Peninsular Malaysia to 203o, (1/2013), Kuala Lumpur, Malaysia.

[13] Chua, SC, Oh, TH 2010, 'Review on Malaysia's national energy developments: Key policies, agencies, programmes and international involvements', Renewable and Sustainable Energy Reviews, vol. 14, pp. 2916-2925.

[14] Cooper, N, Minakata, D, Begovic, M, Crittenden, J 2011, 'Should We Consider Using Liquid Fluoride Thorium Reactors for Power Generation?', Environmental Science \& Technology, vol. 45, pp. 6237-6238.

[15] Danish Energy Agency 2018, Denmark's Energy and Climate Outlook 2018: Baseline Scenario Projection Towards 2030 with Existing Measures (Frozen Policy), Copenhagen, pp. 26.

[16] Department of Statistics Malaysia 2018, Selected Agricultural Indicators, Malaysia, 2017, The Office of Chief Statistician Malaysia, Department of Statistics Malaysia 2017 [cited 10 May 2018].

[17] Economic Planning Unit of Malaysia 2018a, Demand Side Management (DSM) Preliminary Study, Putrajaya, pp. 47.

[18] Economic Planning Unit of Malaysia 2018b, Demand Side Management (DSM) Preliminary Study, Putrajaya, pp. 283-284.

[19] Editorial of Malay Mail 2018, Sabah geothermal power plant project found abandoned, Dewan Rakyat told, The Malay Mail.

[20] Electric Power Research Institute (EPRI) 2008, The Green Grid: Energy Savings and Carbon
Emissions Reductions Enabled by a Smart Grid, California, p. 64

[21] Energy Commission Malaysia. 2015a, Performance and Statistical Information on Electricity Supply Industry in Malaysia 2015, p. 10.

[22] Energy Commission Malaysia. 2015b, Performance and Statistical Information on Electricity Supply Industry in Malaysia 2015, p. 11.

[23] Energy Commission Malaysia 2016a, Guidelines for Solar Photovoltaic Installation on Net Energy Metering Scheme [Electricity Supply Act (Amendment) 2015 (Act A1501)], in P.U.(A) 12O, edited by MEC Department of Electricity Supply Regulation, Kuala Lumpur, Government of Malaysia.

[24] Energy Commission Malaysia 2016b, Malaysia Energy Statistics Handbook 2016, p. 9.

[25] Energy Commission Malaysia 2016c, Malaysia Energy Statistics Handbook 2016, p. 33.

[26] Energy Commission Malaysia 2016d, Peninsular Malaysia Electricity Supply Industry Outlook 2016, p. 45 .

[27] Energy Commission Malaysia 2017, Peninsular Malaysia Electricity Supply Industry Outlook 2017, pp. 24, 32.

[28] Energy Commission Malaysia 2017, Peninsular Malaysia Electricity Supply Industry Outlook 2017, p. 33 .

[29] Forsberg, C, Kazimi, M, Moniz, E. 2011, Future of the Nuclear Fuel Cycle.

[30] Hanwa Q Cells GmBH Hanwa Q Cells GmBH 2014, http://www.q-cells.com.

[31] Haris, AH, Ding, J 2009, Final Report on National Renewable Energy Policy and Action Plan, edited by MBIPV Project c/o Pusat Tenaga Malaysia. 
[32] Hashim, H, Ho, WS 2011, 'Renewable energy policies and initiatives for a sustainable energy future in Malaysia', Renewable and Sustainable Energy Reviews, vol. 15, no. 9, pp. 4780-4787. http://doi.org/10.1016/j.rser.2011.07.073.

[33] International Renewable Energy Agency (IRENA) 2018, End-of-Life Management: Solar Photovoltaic Panels, IRENA 2016 [cited 10 May 2018].

[34] Jaafar, $\mathrm{AB}$ 2015, Future Energy: Is OTEC the Solution?, myForesight,vol. 3, pp. 4-9.

[35] Jaafar, $\mathrm{AB}$ 2017, 'Ocean Thermal Energy Conversion (OTEC)', in National Workshop on Ocean Energy, Universiti Teknologi Malaysia (UTM), Kuala Lumpur.

[36] Joshi, D 2018, Evaluating the Performance of the Sustainable Energy Development Authority (SEDA) and Renewable Energy Policy in Malaysia, Kuala Lumpur, pp. 48.

[37] Kavalec, C, Gorin T 2009, California Energy Demand 2010 - 2020, Adopted Forecast, California Energy Commission, CEC - 200 2009 - 012 - CMF, p. 7.

[38] KeTTHA 2008a, National Renewable Energy Policy and Action Plan. Kuala Lumpur, pp. 32-33.

[39] KeTTHA 2008b, National Renewable Energy Policy and Action Plan, Kuala Lumpur, p. 38.

[40] KeTTHA 2009, Laporan Hasil Kajian Audit Tenaga di Bangunan MOF dan Bangunan EPU.

[41] KUB-Berjaya Enviro 2019, 'Presentation on Bukit Tagar Sanitary Landfill: Our Commitment towards Environmental Protection', in Advanced Training of Trainers (ToT) on River Pollution Public Outreach Programme Kuala Lumpur, Malaysia,
Malaysian Capacity Development Network for Sustainable Water Management (MyCDNet).

[42] Lalchand, G 2012, 'Electricity demand and supply in Peninsular Malaysia: Energy efficiency, renewable energy, or nuclear?', in Malaysia's Energy Challenges, edited by C Teh Boon Sung.

[43] Lam, MK, Lee, KT 2011, 'Renewable and sustainable bioenergies production from palm oil mill effluent (POME): Win-win strategies toward better environmental protection', Biotechnology Advances, vol. 29, pp. 124-141.

[44] Larsen, K 2017, End-of-life PV: then what? Recycling solar PV panels, Elsevier Renewable Energy Focus 2009 [cited 11 July 2017]. http://www.renewableenergyfocus.com/view/300 5/end-of-life-pv-then-what-recycling-solar-pvpanels/.

[45] Loh, SK, Nasrin, AB, Mohamad Azri, S, Nurul Adela, B, Muzzammil, N, Daryl Jay, T, Stasha Eleanor, RA, Lim, WS, Choo, YM, Kaltschmitt, M 2017, 'First Report on Malaysia's experiences and development in biogas capture and utilization from palm oil mill effluent under the Economic Transformation Programme: Current and future perspectives', Renewable and Sustainable Energy Reviews, vol. 74, no. Supplement C, pp. 1257-1274. https://doi.org/10.1016/j.rser.2017.02.066.

[46] Malandrino, O, Sica, D, Testa, M, Supino, S 2017, 'Policies and Measures for Sustainable Management of Solar Panel End-of-Life in Italy', Sustainability, vol. 9, no. 4, pp. 481.

[47] Malaysia, EC, 2015, Performance and Statistical Information on Electricity Supply Industry in Malaysia 2015, pp. 10. 
[48] Malaysiakini 2018, Nuclear power too costly and risky, says Harapan 2017 [cited June 16 2018].

[49] Malaysian Industry-Government Group for High Technology (MIGHT) 2013, Malaysian Biomass Industry Action Plan 2020: Driving SMEs Towards Sustainable Future, Cyberjaya, Selangor, pp. 2.

[50] Malaysian Palm Oil Board 2018, Number and capacities of palm oil sectors in operation as at december 2017 (tonnes/year), MPOB 2018 [cited 10 May 2018].

[51] Mathieu, LH, D.; Brissot, R.; Garzenne, C.; Le Brun, C.; Lecarpentier, D.; Liatard, E.; Loiseaux, J.-M.; Me'plan, O.; Merle-Lucotte, E.; Nuttin, A.; Walle, E.; Wilson, J. 2006, 'The thorium molten salt reactor: Moving on from the MSBR', Progress in Nuclear Energy, vol. 48, no. 7, pp. 664-679. 10.1016/j.pnucene.2006.07.005.

[52] Mekhilef, S, Barimani, M, Safari, A, Salam, Z 2014, 'Malaysia's renewable energy policies and programs with green aspects', Renewable and Sustainable Energy Reviews, vol. 40, pp. 497-504. https://doi.org/10.1016/j.rser.2014.07.095.

[53] Najafpour, GD, Zinatizadeh, AAL, Mohamed, AR, Hasnain Isa, M, Nasrollahzadeh, H 2006, 'Highrate anaerobic digestion of palm oil mill effluent in an upflow anaerobic sludge-fixed film bioreactor', Process Biochemistry, vol. 41, no. 2, pp. 370-379. https://doi.org/10.1016/j.procbio.2005.06.031.

[54] Nelson, J 2011, 'Over the Limit: Strategies for High Efficiency', in The Physics of Solar Cells, Imperial College Press.

[55] NOVAVIRO Technology Sdn Bhd NOVAVIRO Technology Sdn Bhd, 23 August 20102010. http://novaviro.com.my/.
[56] Oh, TH, Pang, SY, Chua, SC 2010, 'Energy policy and alternative energy in Malaysia: Issues and challenges for sustainable growth', Renewable and Sustainable Energy Reviews, vol. 14, pp. 12411252.

[57] Oh, TH, Hasanuzzaman, M, Selvaraj, J, Teo, SC, Chua, SC 2018, 'Energy policy and alternative energy in Malaysia: Issues and challenges for sustainable growth - An update', Renewable and Sustainable Energy Reviews, vol. 81, pp. 30213031.

[58] Ong, HC, Mahlia, TMI, Masjuki, HH 2011, 'A review on energy scenario and sustainable energy in Malaysia', Renewable and Sustainable Energy Reviews, vol. 15, pp. 639-647.

[59] PEMANDU 2010, Economic Transformation Programme: A Roadmap for Malaysia, http://etp.pemandu.gov.my/Download_Centre-@Download_Centre.aspx.

[6o] PEMANDU (Performance Management \& Delivery Unit of Malaysian Government) 2017, Economic Transformation Programme: Palm Oil \& Rubber 2013 [cited $25 \quad$ September 2017]. http://etp.pemandu.gov.my/Palm_Oil-@Palm_Oil_-\%E2\%97\%98-_Rubber.aspx.

[61] Poh, PE, Chong, MF 2009, 'Development of anaerobic digestion methods for palm oil mill effluent (POME) treatment', Bioresource Technology, vol. 100, no. 1, pp. $1-9$. https://doi.org/10.1016/j.biortech.2008.06.022.

[62] REEEP (Renewable Energy \& Energy Efficiency Partnership) 2010, Policy Database: Malaysia (country profile). https://www.reeep.org/

[63] Schaffer, MB 2013, 'Abundant thorium as an alternative nuclear fuel: important waste disposal 
and weapon proliferation advantages', Energy Policy, vol. 6o, pp. 4-12.

[64] Sustainable Energy Development Authority (SEDA) Malaysia 2017, 'Current Status and Projections for RE Power Generation for Malaysia', in Half Day Workshop on Low Carbon Energy Alternatives in Malaysia, edited by ARA Samah, Wisma IEM (Institution of Engineers Malaysia), Petaling Jaya, Selangor.

[65] Sustainable Energy Development Authority (SEDA) Malaysia 2018, Annual Report 2017, Putrajaya, pp. 39, 41, 42, 45.

[66] Sustainable Energy Development Authority (SEDA) Malaysia 2012, 'The Renewable Energy Roadmap', in National Energy Security 2012 Conference, Kuala Lumpur.

[67] Azah Ahmad 2019, Sustainable Energy Development Authority (SEDA) Malaysia, presented during the briefing on the New NEM, Introduction to Self-Consumption (SelCo), and RPVI (Registered Solar PV Investor) Directory Application. Marriott Hotel, Putrajaya, 18 March 2019.

[68] SIRIM 2013, Renewable Energy Resource Map of Malaysia (MYREMap), SIRIM, Shah Alam, Selangor.

[69] Sovacool, B 2010, 'A comparative analysis of renewable electricity support mechanisms for Southeast Asia', Energy, vol. 35, no. 4, pp. 17791793. 10.1016/j.energy.2009.12.030

[70] Subramaniam, V, Ma, AN, Choo, YM, Sulaiman, NMN 2008, 'Environmental performance of the milling process of Malaysian palm oil using the life cycle assessment approach', Am J Environ Sci, vol. 4, pp. 310-315.
[71] SunPower Corporation SunPower 2014, http://us.sunpower.com.

[72] Swedish Energy Agency 2015, Energy in Sweden 2015 .

[73] Tong, SL, Jaafar, AB 2004, 'Waste to energy: methane recovery from anaerobic digestion of palm oil mill effluent', Energy Smart, vol. 14, pp. 4-11.

[74] Tong, SL, Jaafar, AB. 2005, 'POME biogas capture, upgrading and utilisation', in PIPOC 2005 International Palm Oil Congress, Petaling Jaya, Selangor, Malaysia. p. 328-336.

[75] Vega, LA 2010, 'Economics of Ocean Thermal Energy Conversion (OTEC): An Update', in Offshore Technology Conference 2010, Houston, Texas, USA.

[76] Wu, TY, Mohammad, AW, Jahim, JM, Anuar, N 2010, 'Pollution control technologies for the treatment of palm oil mill effluent (POME) through end-of-pipe processes', J Environ Manage, vol. 91, pp. 1467-1490.

[77] Yeo, BY 2018, 'Ministerial keynote address', in International GreenTech and Eco Products Exhibition and Conference Malaysia (IGEM) 2018, Kuala Lumpur, Malaysia. 